\title{
Reversals in Wartime: Alcuin and Charlemagne discuss Retrograde Motion
}

Abstract

1. The inferior planets also display retrograde motion, but when they are at their closest to the earth in inferior conjunction.
The apparent retrograde motion of the planets was a puzzle for astronomers from the ancient world to the final establishment of heliocentric cosmology in the early modern period, but enjoyed an especially rich discussion in the Carolingian Renaissance. We explore the first stirrings of an eighth-century response to this epistemological challenge in a remarkable series of letters between Alcuin of York and Charlemagne, sent while the latter was on campaign against the Saxons in $798 \mathrm{CE}$. Their exchange constitutes the longest discussion of the phenomenon of Mars' retrograde motion in the West up to that date.

Our consideration of the relevant letters explores Alcuin's ability to marshal diverse and complex explanatory narratives and observational traditions around the problem of the retrograde motion of the planet Mars, even as he was unable to fully reconcile them. Attention to his ultimately unsuccessful (and at times contradictory) attempts at explanation suggest that he relied on knowledge from sources beyond those previously recognized, which we identify. Charlemagne's curiosity about the matter can be located in the much longer context of an ancient tradition of imperial and royal concern with heavenly phenomena; at the same time, the exchange with Alcuin heralds the ninth-century expansion of astronomy away from the computists' preoccupation with the solar and lunar calendrical data required to calculate the date of Easter and towards a more wide-ranging curiosity about observed planetary motion irrelevant to Easter dating and computistical calculations. Alcuin's functional, if not geometrical, assumption of the centrality of the sun in his explanation merits a further examination of the more general sense in which lost ancient heliocentric ideas sustained early medieval echoes.

\section{Introduction: Retrograde Planetary Motion and Alcuin's Carolingian Position}

To an observer on planet earth, all the planets appear to travel through the stars from West to East most of the time. However, for exceptional intervals, the outer planets (Mars, Jupiter, and Saturn) become stationary in the night sky ${ }^{1}$ and then can be seen to move, 
for a time, in the opposite direction, a phenomenon known as retrograde motion. This apparent disruption to their accustomed course challenged astronomers from antiquity until the eventual establishment of heliocentric cosmology in the early modern period. The reversed motion is not real, but is an artifact of the observer's observation point on the moving earth. From a geocentric perspective, retrograde motion cannot be satisfactorily explained without resorting to hypotheses that add significant complexity to any prevailing model of planetary motion. Thus, for example, in the second century, Ptolemy had refined Apollonius of Perga's notion of epicycles into a complex system to account for observations of retrograde motion. The Ptolemaic epicyclic model was not the only explanatory scheme available, and was in any case unavailable in extenso to the West before the twelfth century. Before contact with Arab astronomers and the recovery of Greek learning, without the full exposition of Ptolemaic theory, and working from a geocentric vantage point, medieval stargazers in the Latin West lacked the two most important alternative concepts (heliocentricity and a full account of epicycles) that could provide satisfactory explanations of the perceived phenomenon.

Today we understand readily that the phenomenon of the apparent temporary East to West, or retrograde, motion of the planets further from the Sun than the earth (Mars, Jupiter and Saturn) is a simple consequence of observations made from the earth in a heliocentric cosmos (see figure 2 below). But for eighth-century stargazers tracking the course of the planets through the night sky, retrograde motion was a troubling anomaly: there was no fully satisfactory explanation for the way that these planets appeared, periodically, to remain stationary and then to reverse direction for fixed intervals before resuming their dominant eastward course. This phenomenon called out for explanation; it would inspire increasingly refined (and sometimes mutually incompatible) hypotheses until the heliocentric understanding of the universe revealed it to be merely a consequence of a terrestrial vantage point. Aristotle, for example, had drawn on earlier Hellenistic sources to propose, in his De caelo, a complex system of multiple nested rotating crystalline spheres, one for each outer planet and others to compensate each planetary sphere

2. See e.g. Grant 66. Note that for primary source references, both in text and footnotes, the internal divisions of the text will be given. Aristotle, $D e$ Caelo 287a-293a and Aristotle, Metaphysics xii. 8,1073b-1074a. for the motion of its neighbours. ${ }^{2}$ According to his account, counterrotating spheres provided a mechanism for the observed retrograde loops. In the second century, Ptolemy replaced Aristotelian nested spheres with the epicycles of his celebrated system. In his scheme, the planets orbit along these small circles whose centres, rather than 
3. We borrow the phrase from Dobcheva. Eastwood, Ordering 11, 14. The works of Immo Warntjes should be consulted for detailed accounts of aspects of the relationship between computus and astronomy.

4. Bede, On the Nature of Things and On Times Introduction 2-3 and 33-34, and On The Nature of Things cap. 8. Bede, The Reckoning of Time.

5. See Alcuin, Epistulae 237-41 and 249-53: Ep. 149 (implying a lost letter to which replies, which will be designated as $148^{*}$ and Ep. 155 , again implying and quoting from a lost letter sent by Charlemagne, designated as $155^{*}$ ).

6. The essential astronomical studies: Lorhmann and Springsfeld. For background: McCluskey, Astronomies and Cultures and Eastwood, Ordering. For illuminating study of the two letters in a broader cultural context: Dutton and Jaeger. Also Borst, "Alkuin und die Enzyklopädie" which focusses on the letters discussed here chiefly in relation to the saltus lunae rather than Mars. the planets themselves, perform steady geocentric orbits. Thus, according to Ptolemy, retrograde motion results when the epicyclic motion is contrary to the central motion.

When astronomical study in the Latin West contracted under the umbrella of the Easter computus, ${ }^{3}$ the calculations and observations associated with the lunar and solar calendars eclipsed planetary astronomy. We can see these priorities reflected even in Bede's writings, for although he alluded to retrogradation in De natura rerum, he omitted it entirely from both his nearly contemporary De temporibus and from his later, fuller, De temporum ratione; indeed, De temporibus mentions Mars only in connection with names for the days of the week. ${ }^{4}$

It is astonishing that the longest discussion of the phenomenon anywhere in the Latin West before 800 was conducted not in a treatise or encyclopedia, but rather in a series of letters sent to and from a military campaign over 1220 years ago. That exchange took place in 798, between Charlemagne, then campaigning in Saxony, and his advisor, Alcuin of York. ${ }^{5}$ The sources on retrogradation available to Alcuin constituted only a small subset of the full range of ancient thought on the topic. The relevant letters have been studied by Dietrich Lohrmann, Kirsten Springsfeld, Paul Dutton and Stephen Jaeger: ${ }^{6}$ Lohrmann and Springsfeld illuminated the scientific thought, and Dutton and Jaeger, the cultural context and larger landscape of ideas, of Carolingian royal interest in the stars, peace-making and friendship. Our work here builds on their conclusions and suggests that Alcuin's various explanatory forays depend on a wider range of sources than has been recognised hitherto.

In the following section (2) we briefly review our current understanding of, and the historical explanations for, the perceived retrograde motion of Mars and the other outer planets. In (3) we discuss the Alcuin-Charlemagne correspondence, and in (4), we present a conspectus of accounts of retrograde motion and consider their relevance to Alcuin, motivating the discussion of section (5).

\section{Alternative Models and Explanations for Retro- grade Motion}

It will be useful to begin by explaining the phenomenon of retrograde motion as we understand it today according to our heliocentric model of the solar system. Mars, Jupiter and Saturn attain their

Interfaces $8 \cdot 2021 \cdot$ pp. $14-53$ 
Figure 1. The motions that produce apparent retrograde motion. As Earth passes a superior planet, such as Mars, the superior planet will temporarily appear to reverse its motion across the sky. Image and caption credit Brian Brondel, reproduced under license CC BY-SA 3.o from the web. The relative positions of the two planets are shown at five successive times.
7. For a concise conspectus of ancient views, see Sargent; Archimedes, Arenarius 135: 8-19; Plutarch, De facie 923A; Simplicius, On Aristotle's Physics. maximum speeds of observed retrograde motion when in direct opposition to the sun from the point of view of the earth. We can review the heliocentric explanation of retrograde motion using, without loss of generality, the case of Mars as an example. Consider figure 1, representing the orbits of Earth and Mars from a modern understanding of the solar system, gravity and Newtonian/Keplerian orbital dynamics:

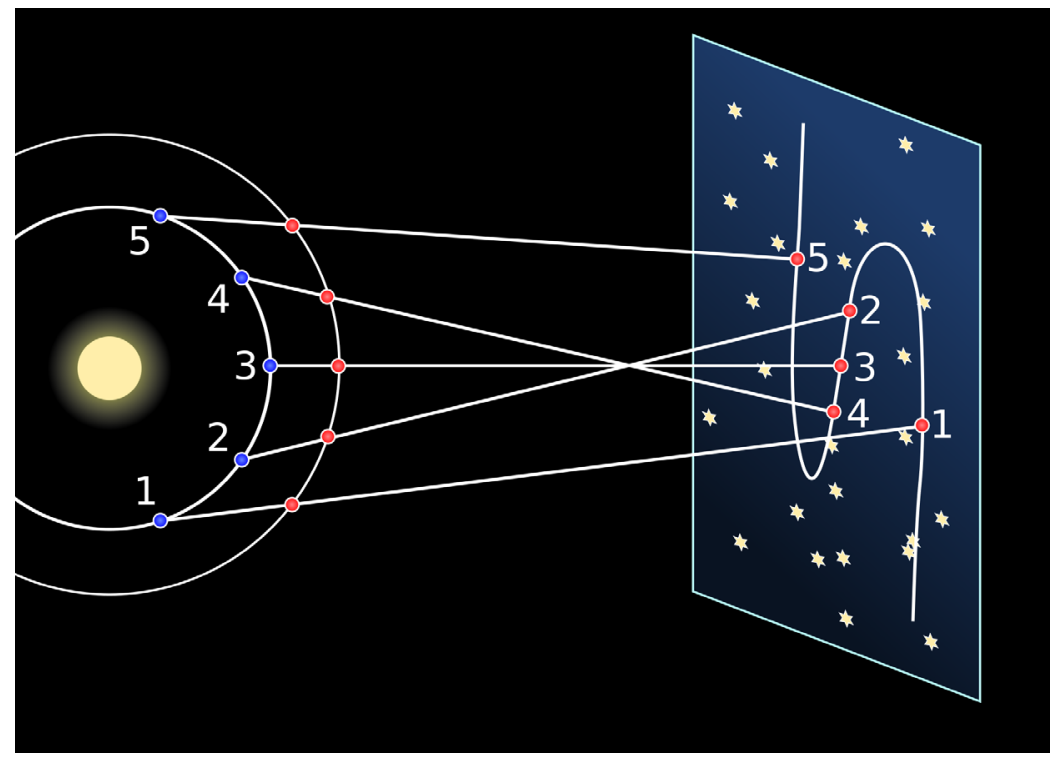

The earth orbits within the orbit of Mars and at a higher angular velocity, both from west to east. The positions of the two planets are shown in the diagram above at five points in a segment of their orbits. Lines of sight projecting from the earth through Mars to the distant stars beyond indicate the apparent position of the planet relative to the stars, as seen from the earth. By construction, the retrograde loop occurs as the earth moves between the sun and Mars. In a geocentric system, relative to an Earth assumed stationary, Mars appears to slow down when the Sun is ahead of the planet in its normal motion along the ecliptic, then to become stationary before reversing. When the sun moves beyond opposition so that it trails Mars, the planet is observed to accelerate into its normal west-to-east motion once more. Such observations made from planet earth correlate readily with a geocentric cosmology. Yet heliocentric views were possible, for various ancient thinkers (whose works survive only in fragments, or secondary accounts) have been credited with advancing heliocentric cosmologies: the firmest claim is associated with Aristarchus of Samos, as attested by existing works from Archimedes, Plutarch and Simplicius. ${ }^{7}$

It is simple to see that observed retrograde motion is correlated 
8. For a comprehensive account of ancient theories of planetary motion see e.g. Gingerich. with the relative positions of Mars and the Sun. Within a notional geocentric cosmos, however, the correlation could logically be misconstrued as solar causation. Specifically, the apparent retrograde motion of Mars is correlatively consistent with the notion of propulsion from the sun's rays, which would at first assist, and then impede, the progress of Mars' orbit, depending on the relative positions of the planet and the Sun. Thus the sun appears to push Mars from whichever part of the sky it occupies: it slows Mars down from its natural orbital motion when its position in the sky seen from earth is in front of Mars; and it accelerates Mars once more when it is 'behind' the planet. This correlation gives rise to the theory, already current in the ancient world (see discussion of sources in section 4 below and, as we shall see, favoured by Alcuin) that the pressure of the sun's rays is responsible for the retrograde loop made by Mars in the sky when it is in opposition to the Sun. The theory is, moreover, consistent with the relative degrees of retrograde motion of all three of the outer planets (Saturn, Jupiter, and Mars), for the retrograde loop is smaller in the case of Jupiter relative to Mars, and is still smaller in the case of Saturn - the latter two being farther from the sun than Mars. Thus the observed retrogradation is consistent with a weaker motive power of the solar rays as they impinge on the more distant planets. Of course, the same diminishing of the retrograde loop can be understood from the geometry of relative distances of the planets in a heliocentric view as well. ${ }^{8}$

It will be important in our discussion of the Alcuin-Charlemagne correspondence to grasp the consequences of the orbital periods of Earth and Mars for the periodicity of Mars' apparent motion relative to the Sun. Because of the 365 -day period of the Earth's orbit within the 687-day orbit of Mars, the interval between successive oppositions (when the Earth comes between the Sun and Mars) is approximately 779 days, about two years and two months. For about a year of this period, Mars will be in the same region of the ecliptic as the Sun. Although formally impossible to observe because of proximity to the Sun for as little as two months, Mars can be very difficult to spot for much longer than this, depending on how far to the south, or to the north, the Sun and Mars are at the times of disappearance and reappearance of the planet. This extended period of observational challenge will be relevant to understanding Charlemagne's queries.

In addition to the illusion of retrograde motion that is the explanation within the Hellenistic heliocentric model, and the posited real retrograde motion from the solar pressure theory that was adopted in some geocentric models, there were at least two other geocentric

Interfaces $8 \cdot 2021 \cdot$ pp. 14-53 
Figure 2. In the Ptolemaic model, an outer planet such as Mars orbits on an epicycle (small dashed circle) whose centre executes a circular orbit ('deferent') centred on a point close to, but not coincident with, the centre of the Earth. Image credit Guan-Ze Liao and Chun-Wang Sun. Web. explanations available from ancient astronomy. However, the slender channels of their transmission via late antique commentators mean that these notions were scarcely available in the Carolingian world. First, the model that was to become most prominent following the twelfth-century translation movement was of course that of the second-century Alexandrian astronomer Ptolemy. The Ptolemaic model transmitted in the Almagest (figure 2) produces actual, rather than apparent, retrograde motion within a geocentric cosmology by attaching the planets to secondary orbits (epicycles) whose centres themselves execute unidirectional motion along a circular path (the 'deferent') whose centre (its 'equant') is close to, but not actually identical with, the centre of the earth. This model thus gives the trajectory of the deferent a circular course even as the motion of the epicycle traces a series of petals along that circular path. Providing that the epicyclic orbital speed of the planet is greater than the orbital speed of the epicycle centre around the earth, there will periodically arise intervals during which the net motion of the planet is opposite to its mean motion (Gingerich).

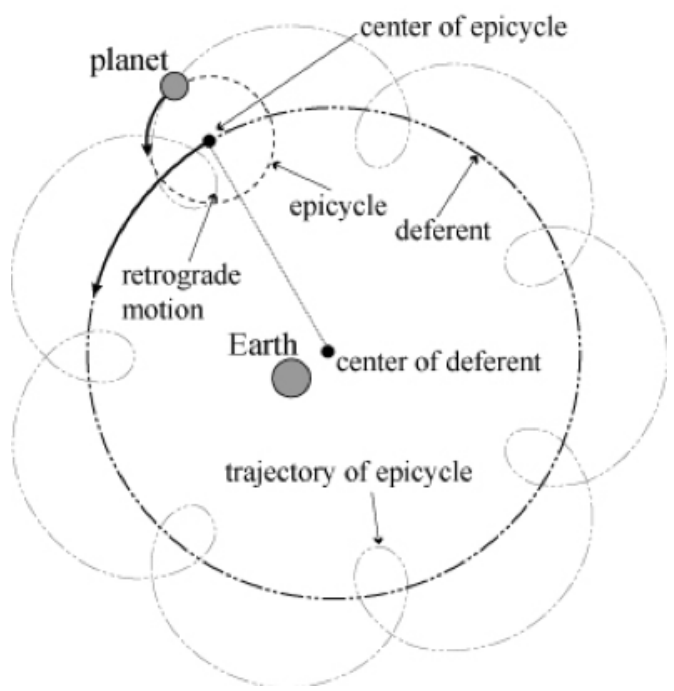

A second class of explanations, also geocentric but not invoking epicycles, refined and added complexity to the ancient cosmos of nested celestial spheres of Aristotle and his precursors. Aristotle himself had drawn upon the earlier scheme of Eudoxus (390-337 $\mathrm{BCE}$ ) which proposed endowing each planet with four or five spheres, rather than one. If each sphere possessed its own axis and rotation relative to its neighbours, retrograde motions could be generated. Alpetragius, in twelfth-century Andalucia, was an exponent of this approach. Though he was a student of Ptolemy, Alpe-

Interfaces $8 \cdot 2021 \cdot$ pp. 14-53 
9. See Al-Bitrūjī, On the Principles of Astronomy, vol. $1,6$.

10. Martianus Capella; Eastwood, "Martianus Capella's Synopsis of Astronomy" in his Ordering 179-312.

11. Annales regni Francorum s.a. 798, 102-06 (even pages). The unrevised Annals tell of the further humiliation that the Saxons took up arms against the Abodrites; also that 4000 Saxons were killed. Other minor annals record the hostage taking. Bohmer-Muchlbacher 152-54; Nelson 324-5. tragius objected on logical and aesthetic grounds to the fanciful epicycles and eccentrics. He accordingly developed his own extension of Aristotle's nested spheres, in which each planet's motion was a result of the compound rotation of a set of concentric spheres, a subset of which generated the apparent retrograde motion. ${ }^{9}$ Ironically, the numerical predictions derived from this elegant refinement of the model were less accurate.

Ancient ideas about retrogradation were primarily transmitted to the readers of the early medieval Latin West by the Latin commentators and encyclopedists of antiquity. Of these, the principal sources were Martianus Capella's On the Marriage of Philology and Mercury, Macrobius' Commentary On the Dream of Scipio, Pliny the Elder's Natural History, Calcidius' Commentary on the Timaeus, and later, works by Isidore and Bede (Eastwood, "The Revival”). We examine the relevant passages from these and other sources in section (4) below, but note here that not all of the work of the commentators was restricted to mere transmission. Martianus Capella, for example, explained the perpetual proximity of the inner planets Mercury and Venus to the sun by centering their epicycles on the sun itself..$^{10}$ This Capellan system, attested in many diagrams of astronomical texts from the ninth century onwards, sustains therefore an explicitly, if partially, heliocentric subsystem, in contrast to earlier Aristotelian and Ptolemaic accounts (Eastwood, ibid.). This complex background of unreconciled explanatory theories (some of which were largely obscured by minimal early medieval dissemination) constitutes the context of the Carolingian correspondence.

\section{The Charlemagne-Alcuin Correspondence}

In 798, according to the nearly contemporary Royal Frankish Annals, the Nordliudi rebelled before Easter:

[they] seized the royal legates who were there with them to do justice. Killing some of them straight away, they kept the rest for ransom; of these some escaped and others were ransomed. The King called the army together, advanced from Herstelle to the place called Minden and after holding a council took up arms against the defectors and ranged across the whole of Saxony between the Elbe and the Weser, laying waste as he went... ${ }^{11}$

Interfaces $8 \cdot 2021 \cdot$ pp. 14-53 
12. Annales s.a. 798, 104: Hoc anno sidus, quod dicitur Martis, a superioris anni Iulio usque ad huius anni Iulium nusquam in toto caelo uideri potuit.

13. Alcuin Ep. 149 and Ep. 155 refer to lost letters of inquiry from Charlemagne.

14. Pliny had noted this difficulty: Naturalis Historia ii. xiv.77. For diagrams of Mars in opposition, see Springsfeld 267-69 and Eastwood, "Diagrams." Alcuin's observations here were the ones included in the Annals and eventually in the Encyclopedia of 809 (Ramirez; Springsfeld).
The later revised version of the Annals supplies a fuller account with more distressing detail about the violence on both sides: a royal legate who was travelling through the region on unrelated business was also slain by the rebels; Charlemagne regarded his expedition as a mission of revenge and "laid waste with fire and sword" that part of Saxony from the Elbe to the Weser (Annales 103). That campaign, and Charlemagne's eventual victory later in the year, occurred between receptions of two major delegations: one from Alfonso of Galicia, which presented Charlemagne with an extraordinary tent, and another from Constantinople. In that same year, too, according to the Annals, Mars, which had not been visible since the previous July, returned to view. ${ }^{12}$ This is the first notice of any an astronomical phenomenon in the Annals during Charlemagne's reign (Springsfeld 272; Dutton 97).

It seems remarkable that Charlemagne found time to concern himself with the planet Mars during such an eventful year, and from the battlefield no less. Yet the disappearance of Mars and its apparently anomalous motion on its return appears to have been a matter of urgent concern. Indeed, he wrote to Alcuin not once, but twice, after having failed to persuade his old advisor to join him on the battlefield. ${ }^{13}$ But of course, it is not the case that Mars' motion had suddenly become irregular, nor that it had actually 'disappeared' for an anomalously longer period than its usual conjunction with the sun that year, but rather, that those reporting these matters to the king were of limited experience in observing and predicting the course of that planet and apparently did not have records of previous observations. (Mars is particularly challenging to bare-eyed star-gazers because it becomes much fainter near conjunction than it is in opposition ${ }^{14}$ and is therefore possible to misidentify through inexperience.) Here, then, we can observe the re-emergence of planetary astronomy in the dialogue between Alcuin and Charlemagne as a project inspired by fresh observation and informed by the reception of written authorities, some previously neglected.

We can also infer the existence of Charlemagne's two letters, which are now lost, from the contents of Alcuin's replies, his letters 149 and 155 . Although the letters reveal that Charlemagne's interest in Mars was intertwined with a range of other learned preoccupations (arithmetic, music, the saltus lunae, the ecclesiastical calendar), we might still want to speculate about some of the reasons for Charlemagne's interest that were not made explicit. Certainly, Charlemagne and Alcuin both would have known that the planet Mars was named for the pagan god of war, who was associated with male warriors, and even, according to Isidore of Se-

Interfaces $8 \cdot 2021 \cdot$ pp. $14-53$ 
15. Isidore Etymologiae VIII.ii. 52-55; Barney 186.

16. On Isidore's distinction between astrologia superstitiosa and naturalis, Etymologiae iii.xxvii.1 and 2: natural astrology is concerned with the solar and lunar orbits and the changing positions of the stars; superstitious, with augury and attempts to link the signs of the zodiac to parts of the human body or soul; or to make predictions about nativity and character. See also Cassiodorus Institutiones II.vii.4; Eastwood Ordering $11,15-16$ and 140 .
17. The tablet is in the British Museum accession number 1891-05-09 Bu, 0014, first edited as tablet 21 (obverse) in R. Campbell Thompson (1900), The Reports of Magicians And Astrologers Of Nineveh And Babylon Vol. 2, London: Luzac and Co. xxxv. This translation is from Hermann Hunger, Astrological Reports to Assyrian Kings (State Archives of Assyria, 8) 1992. Lemmatised by Mikko Luukko 2016-17, as part of the research programme of the Alexander von Humboldt Chair in the Ancient History of the Near and Middle East at LMU Munich (Karen Radner, Humboldt Professorship 2015). The annotated edition is released under the Creative Commons Attribution Share-Alike license 3.o. Web. Accessed 1.9.2020. ville's Etymologiae, with death, ${ }^{15}$ so regardless of one's views on the admissibility of prognostication based on the stars and planets, ${ }^{16}$ the observation of apparent anomalies in the course of Mars might have provoked ominous questions about the orderly governance of the universe and even perhaps adverse planetary effects on human affairs especially, even, on wars. Both, too, might have remembered Julius Caesar's boast in Lucan's De bello civili. After his conquest of Egypt, at a banquet in Memphis, Caesar hoped to induce the local priest and seer to divulge what he knew of the secret knowledge of the origins of the Nile. Caesar declared:

$$
\text { ... In the midst of war }
$$

I ever found time to study the world above us and the starry and celestial zones...

\section{... media inter proelia semper}

Stellarum caelique plagis superisque uacaui... (x.185-86, Duff 603)

Alcuin, who knew Lucan's poem, would surely have remembered that Caesar's civil war had been fought under the baleful sign of Mars. Indeed, in the first book of Lucan's De bello civili, questions about the links between Mars, human affairs, and cosmic order came to the fore. Caesar's poet-astronomer Nigidius Figulus read the strange occurrences in the heavens and declared that either there was no cosmic order at all, or if there was, the prognostics were sinister: Mars would hold the sky and drive other constellations away during the madness of war (Lucan, De bello ciuili i.66o, 663, 669). The parallel between the astronomical interests and consultations of Caesar, and those of Charlemagne and his consultation with Alcuin, would not have escaped the latter. If the resonance between the correspondence between Charlemagne and Alcuin, and the exchange between Caesar and Nigidius, suggest the possibility of a long tradition of kings and their learned advisors discussing the movements of Mars and their meanings, then such a possibility is supported by an even more remarkable parallel text found on a neo-Assyrian (911-612 BCE) tablet from Nineveh. The tablet reads:

Twice or thrice we watched for Mars today (but) we did not see (it), it has set. Maybe thinking my lord will say as follows: 'Is there any (ominous) sign in (the fact) that it set?' (I answer): 'There is not.' ${ }^{17}$ 
18. Alcuin, ep. 149, 242 line 9 and following; Jaeger, Dutton.

19. Folkerts.

20. For the richest discussions of the cultural and ideological dimensions of the letter: Jaeger and Dutton.

21. Alcuin, ep. 149, 242, as translated by Jaeger $106-07$.
Although there is of course no possibility that Alcuin knew of this Assyrian material, it suggests that the dependent parallel with the Roman example should be understood within a tantalising and far longer time-frame: royal concern over possible Martian portents met with scientific advice of natural regularity is an age-old recurrent phenomenon. Such recurrence (or intellectual convergent evolution) reminds us that there is no room for condescension towards the limitations of geocentric explanation and in sketching a narrative of the developments in astronomical knowledge; we should perhaps give credit to every ruler preoccupied enough with planetary observation to have asked the question.

If campaigns against the Saxons were a regular occurrence in the 790 (for Charlemagne had been with his army in Saxony in 796 and 797, as well), so, too, were letters about astronomy and time reckoning. However, Charlemagne's (lost) letter $149^{*}$ to Alcuin written during summer 798 was exceptional, for Charlemagne had begun with the unusual demand that Alcuin prepare a musical composition that could be used on the campaign to calm his savage young warriors. ${ }^{18}$ Arithmetic, too, emerged as a topic of acute interest in Alcuin's correspondence with Alcuin at this time. In other words, Charlemagne was pressuring his most learned courtier to satisfy his curiosity about questions related to almost the full range of quadrivial learningmathematics (likely including both arithmetic and geometry), ${ }^{19} \mathrm{mu}-$ sic, and astronomy. ${ }^{20}$

Alcuin responded to Charlemagne's request by praising the king for asking so wisely and acknowledging Charlemagne's own royal and well-balanced temperament:

[You] also admonished me to mix a sweet melody of versifying amidst the horrible din of clashing weapons and the raucous blare of trumpets, since a sweet and gentle musical refrain can mollify the savage impulses of the mind...

This too you foresaw with wisest counsel, [namely] that wholesome counsel often has no effect on the mind rasped with anger, just as on the contrary, a persistent mental softness is wont to undermine fortitude. But amid these various afflictions, the prudent temperament holds to the middle path... ${ }^{21}$

To continue the account of the letters:

Of this exchange, two letters by Alcuin are now extant; each im-

Interfaces $8 \cdot 2021 \cdot$ pp. 14-53 
22. Epistulae 126, 143, 144 (from Charles), 145, 148, 149, 155, 170, 171. On the group, Lohrmannn 93-96. Springsfeld 261-90.
23. Ep. 149, 243, line 9 and following.

24. Ep. 149, 243, Mars from line 11. plies (and one quotes from) a lost letter from Charlemagne. This surviving pair, in turn, is part of remarkable group of eight letters by $\mathrm{Al}$ cuin and one from Charlemagne which treat diverse questions in astronomy, time reckoning and computus alongside other pressing and topical intellectual and theological concerns. ${ }^{22}$

Alcuin's astronomical correspondence with Charlemagne reveals much, not only about cosmological understanding, but also about the underlying assumptions about the nature, purpose and context of such learning, about learned dialogue and debate, and about patronage between a king and his most learned courtier. A closer look at the letters in question and a consideration of their background makes this clear. Here we précis their contents with especial regard to the question of planetary motion; translations are supplied in the appendix.

\section{Letter 149 summarised}

Alcuin replied to a lost letter from Charlemagne; he had composed the war-song, meant to pacify the young soldiers, and presented it with a courtier's flattering nod to Charlemagne's exemplary regal virtues of temperance, which encompassed self-control and mental stability. He reflected on the ancient historians' teachings on the use of strength, guile, and even peace, as measures to take against an enemy. He went through a stockpile of aphorisms about friendship to affirm his esteem for Charlemagne and his fear of losing the latter's favour. And then he treated the orbit of Mars, its long disappearance, and sudden return, not once, but twice, with reflections on other learned topics and debates interposed between the two treatments.

The first relevant paragraph contains a general account of planetary retrograde motion; Alcuin adopts the solar-ray theory of planetary irregularity: he observes that the sun and the moon are not wandering stars, yet the five planets seem to have an erratic course. ${ }^{23}$

This section implies that both Alcuin and Charlemagne had independently observed this phenomenon that year, and that the astronomical scholars now at court (since Alcuin's retirement) were attempting to explain the phenomenon as well.

In a final paragraph (after almost half a dozen other topics of learned deliberation-including a question from Charlemagne's wife and a lively defence against blaming Alcuin for the scribal error in his earlier exposition of the lunar saltus) Alcuin returned to Charlemagne's question about Mars. ${ }^{24}$ 
25. Ep. 155, 252, line 3 and following.

26. Charlemagne is here suggesting that a conjunction obscured the planet: this is the best explanation, yet according to Springsfeld 277, Alcuin rejects it. We translate differently, with Lohrmann.

27. We here follow Lohrmann 95; cf. Springsfeld 277-78. Springsfeld 274 on the fact that Alcuin and Charlemagne each reported having seen Mars return at different times.
Alcuin affirmed that the disappearance of the planets from view was in fact a regular occurrence according to the ancients, one which, he conjectured, they observed differently in their Southern and Eastern location, since, as Charlemagne knew, difference of place changed many things.

The letter ends with a benevolent analogy: the planets do in fact return regularly; so too may Charlemagne be returned safe from his campaign among the enemies. But what was the question that had elicited this affirmation that the planetary motion, specifically that of Mars, was in fact regular and had underlying rationes? We do not know, because the letter addressed to Alcuin that prompted ep. 149 does not survive; nor does Charlemagne's letter of reply to ep. 149. However, in Alcuin's second letter on the topic (ep.155), part of that lost reply is quoted. Evidently Charlemagne and his advisors found the arguments of ep. 149 insufficient and so took up the matter again.

\section{Letter 155 summarised}

Charlemagne was evidently not satisfied with Alcuin's explanations for the retrograde motion and long disappearance of Mars, for he sent a further letter $\left(145^{*}\right)$ seeking a fuller account of the matter and putting other astronomical questions as well. That letter reached Alcuin while the latter was travelling without his books. Alcuin protested that he was not up to the question, insisting that erratic planetary motion exceeded his grasp. (It is important to separate Alcuin's conventional expressions of modesty and humility from his attempt to answer Charlemagne's questions. Gestures of modesty were an established convention, but we should not be fooled into thinking that Alcuin was not intending to exert himself fully in his reply.) Alcuin alluded to the works of both ancient and Christian authorities on the matter of Mars, singling out Pliny and Bede as the best authorities and suggesting that he could answer better if Charlemagne would send him the first books of Pliny's Natural History. Alcuin took up the challenge all the same, quoting Charlemagne's questions. The king wanted to know whether it was by force or as a portent (prodigium) that Mars had apparently accomplished its orbit of two years in a single year? ${ }^{25}$ Was the cause its own course, or some effect of the sun? Did Mars remain in the sign of the crab even after the sun had moved on to the next sign, and if so, why was it not visible after the sun had progressed $?^{26}$ Or did Mars accompany the sun? Alcuin insisted that the phenomenon was no prodigy, but was part of the planet's natural course. ${ }^{27} \mathrm{He}$ contra- 
28. On the Lucan excerpt, see the notes in the translation in the appendix, p. 30 and 49 note 86 below.

29. Web (visualisation run 17.08.2021). See also Springsfeld 274-76, with tables contrasting the visibility of Mars in Tours and in Verden an der Aller in Saxony. dicted Charlemagne's observation: he did not believe that Mars had remained in the sign of the crab for a full year. He then reiterated the theory of solar-ray impedance from his earlier letter, this time adorning the notion with the same quotation from Lucan that Isidore had used when treating the matter, but slightly mangled, implying faulty memory or scribal error. ${ }^{28}$

There appear to be two problems associated with Mars for Charlemagne (and therefore for Alcuin). The first is the King's report of the lengthy absence of Mars from the sky (two years rather than for the normal two months, when the planet is too close to the sun for observation). The second is the general puzzle of retrograde motion. Alcuin (as do we) doubts the reality of the first, but not the second.

Replicating the course of Mars in 797-98 with a computational orrery reveals the accuracy of Charlemagne's report that Mars had not been clearly visible for as much as a year-although for some of this time, its apparent absence resulted from contingent conditions, rather than retrogradation. ${ }^{29}$ Mars would have disappeared into the evening twilight in Sagittarius, in November of 797, but even before then, Mars would already have been very difficult to see in Europe for several months because of the extreme southerly location of this region of the zodiac, requiring very low and clear south-western horizons and even then appearing for under an hour, and faintly, in the low evening twilight, before setting.

Conjunction with the Sun occurred around April 1798 in the constellation of Aries. Mars would return to visibility, in theory, in the morning half-light of Taurus in July 798 but would probably still have been difficult or impossible to discern because of the early rising of the summer sun and would have remained thus as the summer progressed. By August 27 798, its conjunction with Saturn in Gemini would still be only just visible in the early morning. Finally, Mars would first leave twilight obscuration in the zodiacal constellation of Cancer by the middle of September 798 after effectively more than a year of invisibility to all but those with trained and experienced eyes.

In short, historical calculations of planetary positions reveal that the far southern position of Mars in 797 and its reappearance in summer 798 means that its invisibility period had been significantly longer than usual. Retrograde motion is a 'consistent inconsistency', but an unprecedented disappearance of the planet for over a year would break all regularities identified from ancient times. As we noted above, Charlemagne's puzzlement and Alcuin's quest for an explanation that would

Interfaces $8 \cdot 2021 \cdot$ pp. 14-53 
30. Einhard, Life trans. Dutton cap. 25, 32. Einhard, Vita Karoli cap. 25, 30: In discenda grammatica Petrum Pisanum diaconem senem audivit, in ceteris disciplinis Albinum cognomento Alcoinum, item diaconem, de Brittania Saxonici generis hominem, virum undecumque doctissimum, praeceptorem habuit, apud quem et rethoricae et dialecticae, praecipue tamen astronomiae ediscendae plurimum et temporis et laboris inpertivit. Discebat artem conputandi et intentione sagaci siderum cursum curiosissime rimabatur. protect his attachment to rule-governed planetary motion tell us more about the quality of astronomical observation and reporting in Charlemagne's retinue that they do about (observed) planetary orbits. It is intriguing that Alcuin himself deals with the two issues in a strongly differentiated way, emphasising an underlying regularity of planetary motion (which he can neither observe nor demonstrate), while reaching for material explanations for the apparent anomaly—solar impedance and the artefact of the northern viewing perspective - that exclude the possibility of a prodigious or portentous suspension of natural order.

Charlemagne's biographer, Einhard, who had been an eyewitness to Alcuin's last years at court, recalled that Alcuin was "the most learned man in the entire world" and that the great emperor had "invested a great deal of time and effort studying rhetoric, dialectic, and particularly astronomy with him;" indeed, Charlemagne devoted himself to arithmetic "and with deep purpose and great curiosity investigated the movement of the stars. ${ }^{30}$ The learned monk Notker of Saint Gall, who purveyed stories of Alcuin, but wrote two generations later and without first-hand knowledge, recounted not only that Alcuin alone dared to disagree with Charlemagne, but also that the emperor "received Alcuin with great kindness and kept him close at his side as long as he lived, except on the frequent occasions when he set out with his armies on mighty wars. [He] went to far as to have himself called Alcuin's pupil, and to call Alcuin his master" (Notker, Thorpe, "Charlemagne" cap. 9, 102 and cap. 2, 94-95).

Our received picture of the court, derived from poems, letters, and annals, is of the royal family closely accompanied by a band of aristocratic warriors, courtiers, and officials, together itinerating from palace to palace in a life punctuated by banquets and embassies, with military campaigns almost every spring and summer, and during the winter months, extended sojourns at a small number of favoured residences. From 795, Charlemagne established the novelty of a fixed capital at Aachen and there we can add the spectacle of Charlemagne inviting his sons, nobles, friends, attendants, and body guards, up to the number of a hundred or more, bathing together in the thermal springs for which Aachen (Aquis granensis) is named (Einhard, Vita Karoli cap. 22, p. 77). Not conventionally included in the image of the court, nor even of Charlemagne's studies with Alcuin, is star-gazing, or observational astronomy, which has not usually been considered a significant court pursuit until the reign of Louis the Pious. These letters and other writings by Alcuin suggest, however, that stargazing had become, in the late 790s, a matter of regular

Interfaces $8 \cdot 2021 \cdot$ pp. 14-53 
31. Hartmann.

32. Alcuin Ep. 121, p. 176 lines 32 ff., p. 177. Dutton, Of Carolingian Kings 93. 33. Alcuin Ep. 121, p. 176 lines 32 ff., p. 177.

34. Springsfeld 265 note 645 .

35. Grosseteste's De Sphera, in contrast to the standard text of Sacrobosco, mentions epicycles only in regard to the Moon. attention for Alcuin, Charlemagne and even some of the royal womenfolk (Alcuin Carmina 246, carmen 26, lines 41-44).

Alcuin had retired from the court in 796, when Charlemagne gave him the rich abbey of Tours. The grant of Tours was not just a reward, and not just compensation for wealth and opportunities he had forfeited by not returning to England, ${ }^{31}$ it was also foreseen that he would continue to teach. In a letter to Charlemagne, Alcuin reported on the programme of instruction at Tours: he was nourishing his pupils in both the scriptures and the liberal arts. Yet he mentioned by name only the first and last subjects, grammar and astronomy, describing his teaching of the latter as: "rejoic[ing] to enlighten some about the order of the stars in the firmament, as if painted on the peak of a great man's residence." ${ }^{2}$ Through that metaphor of the lay magnate's magnificent ceiling, Alcuin emphasised astronomy as an observational pursuit, hinting at how it stood apart from ecclesiastical computus. ${ }^{33}$

\section{Accounts of the retrograde motion of Mars}

Until the translation of Ptolemy's Almagest into Latin (from the Greek in 1160, and from the Arabic in 1175) $)^{34}$ scholars in the Latin West drew their picture of the cosmos chiefly from encyclopaedists, commentators, and other intermediate sources without direct access to Ptolemy's writings, although some of these authors (for example, Cassiodorus) had some limited awareness of the existence and contents of Ptolemy's works. In the following, we summarise the relevant writings on retrograde planetary motion and consider both their conceptual implications and their possible availability to Alcuin.

\section{Aristotle (indirect)}

Aristotle's De Caelo would only be known to the ninth-century Latin West through scant indications in intermediate sources, but this famous work, in any case, hardly refers to retrograde motion at all. We will find that later medieval scholars who follow Aristotle over Ptolemy (Grosseteste is an example) ${ }^{35}$ likewise tend to downplay the treatment of retrograde motion. As we have seen, observed retrogradation would eventually be accommodated in the geocentric model via epicycles, but Aristotle held to Eudoxus's concept of planetary motion governed by multiple nested spheres with individual axes and rotational patterns. Observed retrograde motion can be satisfac-

Interfaces $8 \cdot 2021 \cdot$ pp. 14-53 
torily explained by epicycles and an eccentric centre of the universe, but is hard to accommodate within the Aristotelian model of nested spheres in motion around a single centre (as would later be developed by Alpetragius). Epicycles would therefore remain rebarbative to thinkers committed to the symmetry of exact orbital centres. While he spends great length explaining why the swifter planets are the nearer, not the most distant from us, in respect to their difference in rotational speed from the sphere of the stars, Aristotle's comment on the more complex motions of the planets is oblique at best. Indeed, he does not explicitly mention retrogradation:

For this single first motion has to move many of the divine bodies, while the numerous other motions move only one each, since each single planet moves with a variety of motions. (Aristotle, De Caelo ii.12.292b.3o)

When Aristotle summarised and evaluated the cosmological explanations of his predecessors in his Metaphysics, he acknowledged that complex planetary motion derived from nested spheres (as had Eudoxus), while accepting and modifying Callipus's refinement of Eudoxus's model by adding additional impeding spheres to account for the observed motions. He explains this without stating which phenomena necessitated this explanatory effort. We can assume that retrogradation was one such phenomenon:

Callippus assumed the same arrangement of the spheres as did Eudoxus (that is, with respect to the order of their intervals) but as regards their number, whereas he assigned to Jupiter and Saturn the same number of spheres as Eudoxus, he considered that two further spheres should be added both for the sun and for the moon, if the phenomena are to be accounted for, and one for each of the other planets.

But if all the spheres in combination are to account for the phenomena, there must be for each of the other planets other spheres, one less in number than those already mentioned, which counteract these and restore to the same position the first sphere of the star which in each case is next in order below. In this way only can the combination of forces produce the motion of the planets. Therefore since the forces by which the planets themselves are moved are eight for Jupiter and Saturn, and twenty-five for the others, and since of these the only ones which do not need to be counter- 
36. Isidore, Traité de la Nature xxii.3 and xxiii; Etymologiae iii.lxvi.3.

37. Alcuin York Poem, 124, line 1554; Index of Quotations and Allusions, 150. Lapidge 66, 231. Tarrant, "Lucan;" Gotoff's work was not available. acted are those by which the lowest planet is moved, the counteracting spheres for the first two planets will be six, and those of the remaining four will be sixteen; and the total number of spheres, both those which move the planets and those which counteract these, will be fifty-five. If we do not invest the moon and the sun with the additional motions which we have mentioned, there will be forty-seven spheres (?) in all.

This, then, may be taken to be the number of the spheres; and thus it is reasonable to suppose that there are as many immovable substances and principles, the statement of logical necessity may be left to more competent thinkers. (Aristotle, Metaphysics xii.8.11-xii.8.14, 1073b-74a)

\section{Lucan (available)}

Lucan's De bello ciuili included a few memorable lines about the solar-ray impedance theory of retrogradation.

The sun divides time into periods, and changes day for night; and the power of his rays forbids the planets to go forward, and delays their wanderings with stationary periods. (Lucan, De bello ciuili $\mathrm{x}$. 201-03)

Isidore included these lines in his accounts of planetary motion in his De natura rerum and Etymologiae, ${ }^{36}$ works known to Alcuin and Bede. Alcuin, too, quoted the same lines as Isidore and Bede, though with distinctive variants. Lucan's poem itself was also well known to Alcuin and would become increasingly popular from the ninth century on. ${ }^{37}$ Thus Alcuin's reception of a theory of retrogradation transmitted in a complex literary work can invite wider reflections about the setting and cultural purposes of astronomical thought, issues that go beyond the scientific positions expounded (Glauthier). For now it will suffice to briefly supply a fuller context for the theory of retrogradation and the observations about Mars in Lucan's poem. The De bello civili recounts the civil war fought between Caesar and Pompey, who was leading the forces of the senate; the account is framed by two miniature cosmic didactic episodes in book $\mathrm{i}$ and book $\mathrm{x}$. Both episodes include facts about the planet Mars which suggest sinister foreboding about that planet's possible connection to Caesar's civil war; in the second, in $\mathrm{x}$, the final extant book, a supremely learned Egyptian priest, Acoreus, expounds the solar-ray impedance theory of retrogradation in the context of an affirmation of the sacred laws

Interfaces $8 \cdot 2021 \cdot$ pp. 14-53 
38 Preliminary searches have not turned up instances of these variants in Lucan or in Isidore's quotation of the relevant lines.

39 Translation in the appendix to this article. which govern the diverse, yet still orderly, motions of the rapid wandering stars. In Book i, Lucan depicts the poet and renowned astronomer Nigidius Figulus holding forth after other augurers, evoking the sinister, mysterious, and baleful domination of Mars prevailing at that moment. According to Nigidius Figulus, the presence of Mars heralded a time of war and lawlessness when unspeakable wrongs would be 'called heroism' (i.66o-63, 667-68). So the poem depicts astronomy as an imperial concern, and Mars as a subject of scientific, historical, and portentous significance.

We should also note that Alcuin's quotation of Lucan's De bello ciuili in his letter 155 to Charlemagne includes textual variants unique to the earliest manuscript copies of this letter. ${ }^{38}$ Among other changes, Alcuin's letter substitutes petentibus (incorrectly intransitive) for potentibus, so that we should translate the passage as referring to the Sun's "assailing rays" in place of "powerful rays." The variant dramatises the solar impedance theory. ${ }^{39}$

\section{Seneca the younger (possibly direct)}

Excerpts from Seneca's Quaestiones Naturales first appear in the Latin West in manuscripts linked to Alcuin (Hine, "Manuscript Tradition" 558-62; Marenbon 57; Garrison, "The Library" 654; Lapidge 68; Ineichen-Eder 196, 199). Seneca is much more expansive than Aristotle, and considerably less opaque than Pliny. He treats the topic of comets at very great length, even as a starting point for a discussion of the alternatives of a rotating Earth and a rotating heaven. The seventh chapter digresses into the motion of the planets (Seneca, Quaestiones Naturales 129-130, 7.25.1):

These five stars force themselves on our attention, and, as they constantly appear in different places, make us inquisitive; but what their morning and evening risings are, what are their stations, when they move ahead, why they are driven backward - all this we have only just begun to understand. Whether Jupiter was rising or setting or retrograde - for they have applied this term to his retreating - we learned just a few years ago. (Seneca, Quaestiones Naturales 7.25.5, 130)

Seneca then quotes anonymous sources for the claim that celestial bodies cannot stand still or reverse their motion: "the movements of this eternal structure are unalterable" (7.25.6), so is forced to address a question:

Interfaces $8 \cdot 2021 \cdot$ pp. 14-53 
40. Eastwood, Ordering 95-178.

41. E.g. McCluskey 17 .

42. Eastwood, "The Revival;" Ordering 96-99.

43. Jones.
Why is it, then, that some of them look as though they are going backward? The approach of the sun gives them an appearance of slowness, as does the nature of their paths and their orbits, so positioned that at a particular time they mislead observers; thus ships, though they are moving at full sail, nevertheless look as though they are standing still. (Seneca, Natural Questions 7.25.7, 130)

The illustration is tantalizing, for ships look as though they are stationary from other ships maintaining the same course and speed. Is Seneca thinking of an observer on a moving Earth, or simply an observer on the shore at a very great distance from the ship? His reference to the role of the sun in retrograde motion is significant, however, as this is the principal cause invoked by Alcuin. The direct working out of this tradition seems to have its origins, not in Seneca, but in the older Lucan, and its transmission via Lucan to Isidore and Bede. We will take up the significance of Seneca's views again in section (5), below. For now it should be noted that the acquaintance with Seneca revealed by excerpts in the circle of Alcuin does not appear to include book 7 of the Natural Questions, although the absence of testimonies from that book in the relevant collection of excerpts need not preclude its availability.

\section{The Elder Pliny (direct) $)^{40}$}

Pliny's Naturalis Historia has been suggested as a source for Alcuin's solar theory of the retrograde motion of planets dangling participial clause, and indeed, Alcuin himself insisted to Charlemagne that a solution could be found there, but in the very long section of the book that is most relevant (Alcuin Ep. 155, Nat. hist. ii.6-20) ${ }^{41}$ there is no succinct reference to the matter. Pliny's thought is more discernible in the briefer treatments of retrogradation by Isidore and Bede. The first mention of 'contrary' (contrarius) motions of the planets (ii.6) refers not to their retrograde motion, but rather to their normal west-to-east progression as being contrary to the east-to-west rotation of the stellar sphere. The lengthy discussion of planetary motions, especially in ii.13 and ii.14 is contorted and contradictory in places, ${ }^{42}$ as analysed forensically by Jones. ${ }^{43}$ Pliny's discussion of planetary motion is primarily exercised by the variation in the closest and furthest points (apsides) and by the inclinations of the planetary orbits to the ecliptic.

The closest Pliny comes to a discussion of retrograde motion is

Interfaces $8 \cdot 2021 \cdot$ pp. 14-53 
by implication in his treatment of the planets' 'stationary points.' As in Lucan, the propulsive effect of the solar rays, in opposite directions before and after planetary opposition, is invoked:

When struck in the degree that we stated and by a triangular ray of the sun they are prevented from pursuing a straight course, and are lifted upward by the fiery force. This cannot be directly perceived by our sight, and therefore they are thought to be stationary, which has given rise to the term 'station.' Then the violent force of the same ray advances and compels them by the impact of the heat to retire. This occurs much more at their evening rising, when they are driven out to the top of their apsides by the full opposing force of the sun, and appear very small because they are at the distance of their greatest altitude and are moving with their smallest velocitywhich is proportionately smaller when this occurs in the highest signs of their apsides. From their evening rise their altitude is descended with a velocity now decelerating less and less, but not accelerating before their second stations, when their altitude also is descended, the ray passing above them from the other side and pressing them down again to the earth with the same force as that with which it had raised them to the sky from the former triangle. So much difference does it make whether the rays come from below or from above, and the same things occur far more in the evening setting. (Pliny, Naturalis historia ii.13.69-71, translation: Natural History I, 210-211)

It is strange that the observational explanandum here is not the striking retrograde motion, but instead the more subtle variation of distance between Earth and Sun (deduced both through apparent brightness and apparent mean progressive velocity). Pliny does not comment on the contradiction between this passage's theory-namely, the placement of planetary apsides at opposition - and the theory expounded in his earlier identification of the apsides within fixed zodiacal signs for each planet separately. In any case, this general treatment of solar propulsion explains an earlier passage specifically on Mars (ii.12.59-60):

The planet Mars being nearer feels the sun's rays even from its quadrature, at an angle of 90 degrees, which has given to his motion after each rising the name of 'first' or 'second ninetydegree'. At the same time Mars remains stationary in the signs 
44. But see Tupikova.

45. Alcuin, ep. 149, p. 243, line 11; Pliny ii.15. (12).6o, p. 146, line 6 (Jahn); p. 208 (Rackham).

46. Eastwood, "The astronomy of Macrobius," 121; Eastwood, Ordering 31-178; Barker-Benfield, "Macrobius" 224-32 and 228. Tours produced at least two copies of the work in the first half of the ninth century; only one is now extant: Paris, Bibliothèque nationale lat. 6370, on which Bischoff, Katalog iii, No. 4403, p. 117, with a later date than Barker-Benfield. Since other evidence of the ninth century reception of Macrobius is linked to Tours and to Alcuin's intellectual grandchild, Lupus, it is tantalizing to consider that may have paved the way for a revival of interest. of the zodiac for periods of six months (otherwise having a two-month period), whereas Jupiter and Saturn spend less than four months in each. (Pliny, Naturalis Historiae ii. xii.12.59-60, translation: Natural History I, 208-09)

Pliny's final discussion within his section on planetary motions concerns the inferior planets Mercury and Venus. He discusses at length two problems: (i) that these planets never wander more than specific limiting angles from the sun; (ii) that the variation in progressive rates along the ecliptic is opposite to that of the superior planets (ii.14). His geometrical language is hard to interpret without diagrams, ${ }^{44}$ but supports both geocentric and heliocentric construction ("as much of their circle is below the earth [sub terra] as that of the planets mentioned before is above it") (Naturalis Historia II.14.72; Eastwood, "Diagrams" 200-06).

Although consistent with the mechanism that Alcuin invokes with more clarity, the effect of 'fiery force' and 'feeling the sun's rays' on the part of the superior planets in general, and Mars in particular, is not clarified in Pliny other than by his assumption that it belongs to the planet's motion, and can be imagined as a triangular geometric construction. In addition to the reference to solar force, a further indication that Alcuin really did have Pliny's discussion at the back of his mind, even with some confusion and without the book at hand, might be inferred from his use of the exceedingly rare word bime(n) stris, recalling Pliny's phrasing ${ }^{45}$ and in the explicit mention of a maximum period of invisibility of each planet (in the case of Mars, Pliny states this to be 170 days, in ii.15.78).

\section{Macrobius (not used by Alcuin)}

Although Macrobius's Commentary on the Dream of Scipio was apparently not used by Alcuin (it is attested at the Carolingian court for the first time through the correspondence of Dungal in 811 and there is continental evidence for an earlier phase of Irish reception), ${ }^{46}$ we include its brief reference to retrograde motion here for completeness. The final paragraph of chapter 19 reads:

Indeed, Plotinus declares in a treatise Are the Stars Effective that the power and influence of stars have no direct bearing upon the individual, but that his allotted fate is revealed to him by stations and direct and retrograde motions of the seven planets, just as birds in flight or at rest unwittingly indicate 
47. Ibid. xix.18, p. 166.

48. For the Latin text: web. future events by their direction or cries. And so we have good reason to call this planet beneficial and that one baneful since we obtain premonitions of good or evil through them. (Macrobius, Commentary on the Dream of Scipio xix.27, p. 168)

Macrobius himself was highly ambivalent on the question of human planetary influence and portent. Indeed, he had sharply undercut the notion that planets had any relationship with the sources of their names in a discussion shortly before the quotation above. ${ }^{47}$ The passage quoted above is the only discussion of retrograde motion in his astronomical work. Given the extreme length that Macrobius devoted to the question of the ordering of the spheres of Mercury, Venus and the Sun, as well as to the question of whether and how the planets and fixed stars differ from each other, it is intriguing to consider whether his brevity on retrogradation might arise from some unease with the matter, perhaps because of the troubling apparent irregularity. It is tantalizing to consider whether Charlemagne's persistent curiosity about the significance of Mars's seeming anomalous course might have derived from a member of his entourage who associated retrogradation with portents from reading Macrobius, or whether, instead, the momentous historical context of Lucan's account might have suggested that the topic was a proper concern for warriors with imperial aspirations.

\section{Martianus Capella (possibly direct)}

Book 8 of Martianus Capella's The Marriage of Philology and Mercu$r y$ was of signal interest for Alcuin's intellectual heirs in the ninth century, and contains an extended section on astronomy with notions not available in other compendia (Eastwood, Ordering 179-87; 299303). Among the distinctive views Martianus advances is his partially heliocentric scheme in which Mercury and Venus orbit the sun, rather than the earth (viii.857). Retrograde motions are correctly assigned to the opposition of the outer planets, with respect to the sun, and at the very end of the section attributed to the force of the sun:

The powerful effect of the sun's rays is responsible for the anomalies in the orbits of all the aforementioned planets and for their stations, retrogradations and progressions. The rays strike the planets, causing them to rise aloft or to be depressed, or to deviate in latitude or to retrograde. (Martianus Capella viii.884, p. 343$)^{48}$ 
49. Lapidge, Anglo-Saxon Library 44 (Tatwine) and 187, 200 (Bede and his use of Martianus in De natura rerum XVII.I).

50. Eastwood, Ordering 314 note 3 for the earliest witness, Paris, Bibliothèque nationale, lat. 2164; for its date and provenance: Bischoff, Katalog iii: 63, no. 4139: a centre close to the court, s. viii/ix or s. ix.

51. Munich, Bayerische Staatsbibliothek, clm. 18961; Latin text edited by Marenbon, From the Circle of Alcuin 167); see also Ineichen-Eder 169, 199.

52. Marenbon 167; our translation; bracketed words from Calcidius, ii.304, pp. 602-03. See also Eastwood, Ordering 313 .
Note that the solar rays are here not only ascribed responsibility for retrograde motion but also for the changes in elevation of the planets' orbits. Martianus's account of retrogradation is closely similar to Pliny's ( $N H$ 2.60) and both may depend on a lost manual by Varro (Stahl, Johnson and Burge, Martianus vol. 1, 199-200 and 200 note 96). Alcuin is not known to have quoted or named Martianus, and is assumed not to have known his work. Both Bede and Tatwine had read the de Nuptiis however and it would be intensely studied and annotated in the ninth century. ${ }^{49}$

\section{Calcidius' translation and commentary on book 1 of Plato's Timaeus (possible direct source)}

Calcidius did not become a major source for astronomical study until well into the ninth century, but the earliest extant witness dates from the reign of Charlemagne and is from North-West Francia. ${ }^{50}$ Furthermore, a collection of excerpts associated with the circle of Alcuin's students transmits a direct quotation from Calcidius in a passage about the order of the world..$^{51}$ That passage, in turn, is closely followed by excerpts from Seneca (Marenbon 56-57; Ineichen-Eder 196, 199). Together this evidence bears witness to an early phase of reception and discussion of these sources before they were taken up into the mainstream astronomical tradition a few decades later. This passage offers a very strong affirmation of a rule-governed planetary order transcending apparent disorder and reads as follows (with the words from Calcidius II.304 in brackets):

The universe is constructed in a superlatively ordered manner. [Order however cannot exist without harmony. Harmony at last is the companion of analogy. Analogy is the same with Ratio, and Ratio is the undivided companion of providence. There is no providence without intellect and no intellect without mind.] The mind of God therefore, since it is intelligence alone, is said to be provident... ${ }^{52}$

Calcidius's Book 5, On the Fixed and Wandering Stars, refers to matters related to retrogradation a number of times (Calcidius 5.69, 70, 77, 79, 85 inter alia). Most of the discussion leans towards an illusory interpretation of planetary retrograde motion "giving the appearance of being contrary that that of the universal sphere" due only to our perspective from the inconstant Earth (there are other echoes of heliocentricity in Book 5.72 where the 'middle position' occupied by the Sun is likened to

Interfaces $8 \cdot 2021 \cdot$ pp. 14-53 
53. Alcuin, De uera philosophia PL 101, col. 833, recalling Cassiodorus, Institutiones ii praef.2. that of the human heart). Yet superficially the text is robustly geocentric. In contrast to the other encyclopaedists, Calcidius does present epicycles and eccentrics, even referring to detailed geometric diagrams, but his worked example is the Sun throughout most of the text, rather than the outer planets. He attributes to Aristotle the opinion that planets would not follow paths such as epicycles. Finally, however, and with some degree of apparent reluctance, a full epicyclic explanation of planetary retrograde motion is given in 5.85. That a full Carolingian reception of this work was delayed to after Alcuin's time is consistent with his apparent unawareness of epicyclic theories of retrograde motion.

\section{Cassiodorus (direct)}

Among the encyclopedists, Cassiodorus' Institutiones is a significant source for the transmission of ancient teaching about planetary motions and was certainly known to Alcuin..$^{53}$ Cassiodorus at least demonstrates some knowledge of Ptolemy: he alludes to his works, though not completely accurately, and appears to have known them to some extent, whether directly or by reputation. (On the question of Cassiodorus's acquaintance with Ptolemy, compare Eastwood, Ordering 3 and Courcelle 352-53.) His mention of retrograde motion is not structured by mechanism, but rather occurs in a list of nomenclature, as if a bare summary (Cassiodorus, Institutiones ii.7.2, Mynors 154-55; Halporn 226-27):

The backward motion or regression of the stars is what the Greek call hypopodismos or anapodismos, i.e., when the star in carrying out its motion seems to be moving backwards at the same time.

The Greeks call the pause of the stars stirigmos because stars, although always in motion, yet [nevertheless] at certain places seem to stand still. Varro $\{$ in $\}$ the book that he wrote On Astrology says stars are named from standing still. (Cassiodorus, Institutiones trans. Halporn, ii.7.2, pp. 226-71)

It is also unclear whether the retrograde motion discussed here refers to the specific effect (relative to the planet's normal motion against the stars) or to the simple observation that the normal motion of planets is from West to East - i.e. 'retrograde' with respect to the sphere of the stars (see also on Aldhelm below). The loss of Varro's writing on astronomy is a grievous one; Varro seems to have taken some idiosyncratic views, such as maintaining the ovoid nature of the shape of the Earth. Cassio-

Interfaces $8 \cdot 2021 \cdot$ pp. 14-53 
54. Halporn and Vessey, Cassiodorus notes to 227; web. Courcelle 352-53, Eastwood Ordering 3.

55. On Cassiodorus and Martianus, see Halporn and Vessey's introduction and apparatus, 27-28, 65, 72, 188 and 208. Eastwood, Ordering 3 ; Courcelle 335.

56. Cassiodorus, Variae 40, i.45, pp. 39-41 at 40; Barnish, Variae 20-24 at 21.

57. Berschin, Greek Letters 15; Cassiodorus, Variae i.45.
58. Isidore, De natura rerum xxii.3, lines 22 and following; Traité, pp. 254-256. dorus never quotes from Ptolemy's Almagest but he does refer to 'canons' of Ptolemy, which may refer to the 'handy tables' of celestial motions derived from the principal work. ${ }^{54}$ Cassiodorus claimed not to have been able to obtain the work of Martianus Capella. However some scholars have suggested that Martianus's influence can be detected in the final version of book II of Cassiodorus's Institutiones. ${ }^{55}$

In sixth-century Italy, before his retirement to Vivarium, Cassiodorus, in the persona of King Theodoric, wrote a letter to Boethius, praising Boethius for his translations from the Greek which had enabled 'the musician Pythagoras' and the astronomer Ptolemy, among other writers, to become as well-known as if they had Italian in translations so elegant that a bilingual reader would prefer Boethius's versions to the original. ${ }^{56}$ Neither translation survives (if it ever existed), but a letter of Gerbert of Aurillac in 983 appears to suggest that he may have known that translation of Ptolemy. ${ }^{57}$ Cassiodorus's letter mentions much else, including a water clock, a sundial, understanding the heavens, and the practical application of knowledge, both in engineering and for curiosities such as a statue that appeared to speak. It appears to be a purple prose set piece about learning, astronomical, mathematical, and mechanical arts, about understanding nature, and about applying that understanding.

\section{Isidore and Bede (both available to Alcuin)}

The De natura rerum and the Etymologiae of Isidore contain more explicit references to the mechanism of retrograde motion:

Stars impeded by the rays of the sun are made irregular or retrograde or stationary, according to what the poet recalls when he says ( $c f$. Lucan, Civil War x.201): "The sun divides the seasons of time: it changes the day to night, and by its powerful rays prevents the stars from proceeding, and delays their unfixed courses with stationary episodes." 8

Isidore is ambivalent, however, as was Seneca before him, on whether retrograde planetary motion is real or illusory. In the Etymologiae, just a few paragraphs beyond the quotation from Lucan he writes:

Recession [remotio], or retrograde motion, of stars occurs when a star, although driving its own motion, at the same time seems to move backward. (Isidore, Etymologiae III. lxix.10, 158; Etymologies 104) 
59. Isidore, De natura rerum, xxii.3, p. 155 lines 17 and 18.

6o. Op. cit. xxiii.3, pp. 258-59, lines 24-27, following Fontaine's translation.
In his De natura rerum, Isidore had treated planetary motion at greater length (Denatura rerum xxii.3 and xxiii), eventually deploying the same lines of reasoning as Lucan. He recognized that the motion of the wandering stars, or planets, contrasted with that of the other stars and occurred according to unfixed rules; the stars were placed at diverse heights, so that those farther appeared to repeat their courses more slowly, yet nonetheless all return at their time to complete their proper course (Denatura rerum xxii.1-3, 254-55). In contrast, the planets subject to retrogradation are "stars impeded by the rays of the sun made irregular or retrograde or stationary, according to what the poet recalls," Isidore wrote and rounded off the brief definition with the authority of Lucan's words from De Bello Civili x.201-3 instead of any fuller explanation. ${ }^{59}$ Isidore's commitment to an ultimate cosmic order despite his failure to adequately explain the apparently irregular course of the planets with retrograde motion emerges when he doubles back to the topic (DNR xxiii.3) insisting that the wandering stars do not derive their name only from their own wandering, but also because they cause us to err (xxiii.3, 258-59) this, even as he affirms that retrogradation is an anomalous departure from a course. Isidore also implies that solar-ray induced retardation and retrogradation, though anomalous, is nonetheless a quantifiable deviation from a fixed course.

[The planets] undergo retrograde motion or are rendered anomalous, when they add or remove fractions [of their courses]; when they remove them only, they are tered retrograde; they are stationary when they stand still. ${ }^{60}$

Bede is less equivocal, taking his cues mainly from Pliny but also from Isidore, chiefly from the latter's fuller account in De Natura Rerum (which he otherwise avoided) but also from the Etymologiae. In his own On the Nature of things, in a passage which, like much of the work, is a tissue of quotations, he wrote:

Seven stars, which are called wanderers, hang between heaven and earth, separated by fixed intervals. They move in a course contrary to the world, that is, to the left, with the world always advancing to the right. And though they are borne along by it with a constant revolution of great speed and are precipitated toward the west, nevertheless they are observed to go with an opposite motion through their own several tracks, wandering now lower, now higher, on account of the obliquity of the zodiac. But, impeded by rays of the

Interfaces $8 \cdot 2021 \cdot$ pp. $14-53$ 
61. Aldhelm, Ad Acircium, Lapidge and Herren, 42; Ehwald, 72 line 5 and 73 lines 11-14. sun, they become irregular, or retrograde, or stationary. (Bede, On the Nature of Things 12, 80-81. The passage is a tissue of quotations.)

\section{Aldhelm (known to Alcuin)}

The pioneer of Latin verse in early medieval England, Aldhelm $(+709)$ mentioned retrograde planetary motion twice in his Letter to Acircius, an eclectic opus which included, after an exordium to its royal dedicatee, an exposition of the significance of the number seven in biblical numerology, a treatise on hexameter verse composition and a hundred riddles. The allusions to retrogradation occur as learned digressions in the section on biblical numerology; they reveal acquaintance with Isidore's Etymologiae and De natura rerum.

Nor is the supernal and celestial creation itself known to want a figure of the same sort of calculation, since the corporeal structure of the visible world is surrounded and girded by the seven orbs of the heavens that incline headlong with the swift impulse of the revolving sphere, although they are retarded by the retrograde courses of the planets. ${ }^{61}$

This final example constitutes a warning, however, against the simplistic assumption that all classical uses of 'retrograde' (Latin retrogradi and cognates) refers to the planetary loops now termed 'retrograde motion. For here (and also possibly in Cassiodorus and others, as discussed above), the term seems to apply to the normal West to East course of the planets, which is 'retrograde' to the diurnal motion of the sphere of fixed stars.

In summary, the sources available to Alcuin on the phenomenon of retrograde motion constitute a surprisingly rich, if equivocal and sometimes contradictory resource. Two contrasting theories predominated-first, there is the notion of some kind of illusion of motion, and second, there are theories that invoke the direct effect of the sun's rays on the planets. The themes of heliocentric models, on the one hand, and epicyclic, on the other, are not entirely silent in these sources, but are much more subdued. Alcuin works with this material alongside other considerations, such as the separation in time and space between his own observational viewpoint and those of the ancients. He also draws on a deeply held metaphysical and theological commitment to ordered motion which he articulates repeatedly alongside other explanations.

Interfaces $8 \cdot 2021 \cdot$ pp. 14-53 
62. On the transmission of Pliny: Reynolds, "Elder Pliny" 307-16; Borst, Das Buch der Naturgeschichte; Reeve's ongoing studies qualify those accounts in important respects: see his "The Editing of Pliny's Natural History." Eastwood, Ordering 95-178. On the study of Pliny in Alcuin's York and contrast between Insular eighth-century reception and exiguous continental pre-Carolingian evidence, Garrison, "An Insular Copy" 67-68. For Irish study despite the lack of manuscript witnesses: Corrigan.

63. Reynolds, "The Elder Pliny" $307-316$ but note the corrections of Reeve.

64. Augustine, On Christian Teaching 56-57, 2.112-114, pp. 56-7; Burton, "The Vocabulary"; Wallis and Kendall Bede: On the Nature of Things, 5, 7 and Wallis, Bede: The Reckoning of Time xxvi-xxix.

65. Stevens, "Astronomy in Carolingian Schools" 417-88; Eastwood, "The Revival" 109-11; Dobcheva; McCluskey, Astronomies and Cultures $131-64$.
When Alcuin and Charlemagne were writing, Macrobius, Martianus Capella and the commentary on the Timaeus by Calcidius were not widely studied and are not generally thought to have been used as sources for astronomy. They would come into use, and greatly enrich humans' ability to discuss a wide range of topics from the 820 s onward (Eastwood, Ordering 10-13; Dobcheva). Yet even the use of Pliny here marks a salient advance, for there is only the scantest evidence for any study of Pliny on the continent between Isidore and before the arrival of Alcuin. (Indeed, all, or all but one, of the five late antique witnesses had been palimpsested or reused for binding before 800 and there is no continental evidence comparable to the eighth-century Northumbrian Pliny excerpts that were eventually transmitted to the continent). ${ }^{62}$ Pliny's books ii and xviii constituted the best pre-Ptolemaic account of the earth-centred universe.

798 can thus be seen as a turning point in the history of the reception of Pliny's Natural History, with the first full copies of the work being reassembled just before 800, at the Carolingian Court, or closely linked centres. ${ }^{63}$ Bede's remarkable astronomical achievements relied chiefly on Pliny's information, with only a limited admixture of Isidore. Yet Bede, for all his remarkable learning, had directed his research and teaching to the monastic life, above all, to explaining the calculation of Easter while invoking a limited range of observational discoveries. As Faith Wallis has emphasised, Bede avoided using the names of the disciplines of the liberal arts, just as Augustine, too, had eschewed them in his work On Christian Teaching, which advocated a retreat from astronomy. ${ }^{64}$ Historians of the field have characterized the pre-Carolingian eighth-century engagement with the skies as chiefly preoccupied with computus, and with the solar and lunar cycles, rather than the other planets. ${ }^{65}$

\section{Discussion}

In the light of the Alcuin-Charlemagne correspondence and the observations that provoked their discussion, the year 798 might be regarded as an inflection point in the history of Astronomy in the Latin West. We meet Alcuin as a thinker indebted chiefly to Plinian, Cassiodoran, Isidoran and Bedan concepts, doing what he can with perhaps some minimal reception of Macrobian and Calcidian ideas. Alcuin's thought was informed by his chief sources (Pliny, Bede, Cassiodorus, Isidore), yet his use of them seems also to be shaped tanta-

Interfaces $8 \cdot 2021 \cdot$ pp. 14-53 
66. Alcuin, ep. 149, 243, lines 15-17: et ideo forte errantes dicuntur, quia certum semper et unius modi cursum non habere noscuntur. Compare Isidore, Etymologiae iii.66. lizingly by familiarity with the explanations of the more indirect sources-Seneca and Calcidius. In all, the correspondence demonstrates an unprecedented degree of interest in retrograde motion on the part of both Charlemagne and Alcuin; this interest is especially striking considering the limited attention to retrogradation in the earlier sources (such as Pliny and Macrobius) which otherwise treat planetary motion in some detail. If further evidence for his prioritising of this particular aspect is required, he is unique, as far as we can find, in ascribing the rationale for the epithet 'wanderers' to the planets to retrograde motion itself, rather than to the primary motion of the planets against the fixed stars. As Alcuin stated in letter 149:

And on that account they are said to be wandering, since they are known not to have an ever-fixed course of a single type $^{66}$

In addition, as Springsfeld has observed, Alcuin breaks new ground, standing apart from Bede, for example, in distinguishing the sun and moon from the other planets (Springsfeld 270-71).

The sources we have quoted above, and other older Hellenistic astronomies (which are the first known to contemplate heliocentric cosmologies) provide four families of explanation of retrograde motion (principally of Mars, but to a lesser extent the other outer planets as well) that appear to some extent in all writings up to the early modern period:

Illusion of motion. In both Seneca and Isidore this seems to be a generalised but unspecific recollection that motion of bodies at a great distance can be deceptive and even appear contrary or stationary. The heliocentric (Aristarchan and Copernican) model belongs to this class, as there, retrograde motion is explained as an illusion of relative motion of the planet and the Earth.

Epicycles. This is the central feature of the Ptolemaic model (and in the Capellan, where the epicycles of Mercury and Venus are centred on the Sun), and produces retrograde motion within a geocentric cosmology directly by attaching the planets to secondary orbits (epicycles) whose centres themselves execute unidirectional motion along a circular path within the planet's celestial sphere.

Propulsive effect of solar rays. This is the explanation adopted by 
Alcuin and derived from Pliny. It is physically motivated and compatible with observed correlations. It also dispenses with epicycles (although in the case of Alcuin, his second hand knowledge of Ptolemy via Cassiodorus's brief allusion would not have included their consideration in any case, and so he does not appear to have needed to reject them.)

Alpetragius' (development of Aristotle) nested spheres. Alpetragius, a scholar of twelfth-century Andalusia, was aware of Ptolemy and studied his system, but held aesthetic and logical objections to the fanciful epicycles. Instead, he proposed an extension of Aristotle's nested spheres, in which each planet's motion was a result of the movement of a larger set of spheres, a subset of which generated the apparent retrograde motion.

One of the most intriguing aspects of Alcuin's correspondence, his sources, and the picture that emerges when these are placed alongside each other, is a repeated distant echo of heliocentic ideas. The solar ray theory of retrograde motion, after all, places the sun in the causative centre of this most puzzling of planetary phenomena. So, in regard to the passage by Seneca, and echoed by Alcuin's attribution of the force of the sun to the retrograde motion of Mars, we have a possible source for the solar ray theory that connects the first and third families of the list of explanations. As pointed out by Russo (294 see also 178 and 293-95) the passage in Naturales quaestiones (already quoted) contains a very clear prohibition on actual, rather than apparent, retrograde motion:

You are mistaken in thinking that any star stops on its track and turns backward. Heavenly bodies cannot be detained or turned back; they forever move forth; as they once were set on their way, so they continue; their path does not end but with their own end. (Russo 294, Seneca vii.25,6-7)

The key phrase in the following passage that attributes effect to the sun - solis occursus - explains the apparent backward motions "like ships appearing stationary." Although an apparently reversed motion arising from a combination of constant motion on multiple circles would, in principle, be consistent with Ptolemaic epicycles, there would in that case be no need for Seneca's explicit invocation of a specific role for the sun. (Thus, although he does not specifically disavow them, we can see that Seneca did not allow epicycles.) Further- 
more, the comparison to moving ships strongly suggests that Seneca's naval observers might themselves have been aboard ship, so that the observation of reversed motion of another planet becomes simply a consequence of relative forward motion of the observer. A final piece of circumstantial evidence suggesting a heliocentric interpretation of the passage is provided by Seneca's explicit discussion of the rotational motion of the Earth as an explanation of the apparent diurnal rotation of the skies (Seneca, Quaestiones Naturales 7.2.3). While diurnal rotation of the Earth and its putative orbital motion around the sun are by no means the same thing, and are potentially independent causes of effects, they occur almost invariably together in discussions of alternative cosmologies from ancient to early modern texts.

Seneca's implied solar causation, in this interpretation, is therefore due to the sun's centrality in relation to the orbits of both Earth and Mars, rather than to the pressure of its rays. Without a putative central location for the sun, the relative motion from differential orbits of the two planets is not defined. However, the Seneca passage is far from clear; when other interpretations are equally present in the sources, and as we have noted, retrograde motion is always correlat$e d$ in the same way not only with the current positions of a retrograde planet and the sun in the sky but also with the history of those positions, then a direct causal influence of solar rays becomes a possible interpretation (if only partial - for the prohibition on actual reversal must be forgotten). The geometric centrality of the sun is then lost and translated into a radiative centrality of cause and we arrive at the most memorable articulation of the model, Lucan's account of the reply of the Egyptian sage Acoreus to Julius Caesar, the lines adopted by Isidore and Alcuin (Lucan, De bello ciuili x.194-210):

... the power of his rays forbids the planets to go forward, and delays their wanderings with stationary periods. (Lucan, $D e$ bello civili $\mathrm{x} .2 \mathrm{O2}-\mathrm{O} 4$ )

Alcuin's written responses to his king echo perfectly those of an earlier sage philosopher to an earlier ruler. They may also represent similar translations, or faulty transmissions, of one notion of helio-centrality to another, one from early antiquity (Aristarchus of Samos) one from late (possibly Seneca), by which a geometric centrality of the sun is replaced by a causative centrality of its rays. 


\section{Conclusion}

There are more questions raised than answers from this brief study of a remarkable Carolingian astronomical correspondence and a consideration of its possible sources. The most radical of our suggestions is that the solar-pressure account that Alcuin proposes to Charlemagne is actually an earlier innovation that arises through miscommunication and partially-understood reception of an originally heliocentric hypothesis.

By considering Alcuin's explanations of retrogradation in relation to earlier hypotheses we can see that his work also marks an inflection point. Alcuin was grappling with this question at the limits of what was possible at the time. His brave and eclectic yet ultimately unsatisfactory attempts appear to depend on a wider range of reading than Alcuin acknowledged, or had been previously recognised as well as on novel observational data. The correspondence about Mars was conducted before, or just as, some of those sources came back into circulation. And it heralds (but predates by some decades) the distinctive rebirth of planetary astronomy for non-computistical purposes; it is significant that this advance took place in the milieu of a king and an advisor who shared a deep commitment to the notion of celestial order: their shared curiosity about Mars may have been sharpened by the example of Caesar, or by a real, but unarticu-

67. For the richest discussion of the larger intellectual themes raised by royal stargazing, see Dutton and Jaeger. For further discussion of Alcuin's poetic expressions of his conviction of divine harmony underlying even seemingly disorderly phenomena in the natural world and the universe, see Garrison, "Alcuin carmen ix." lated concern with prognostics, but certainly, they were intent on the pursuit of a better understanding of the cosmos. ${ }^{67}$ And despite the difficulty of the question, which Alcuin acknowledged fully, as well as the disturbingly irregular observational data that he and Charlemagne had noted, Alcuin nonetheless concluded his exchange with Charlemagne by insisting that the motions of Mars, however puzzling, must have natural explanations, and that the king should not read into them any suspension of regular cosmic order and certainly not any portentous implications for current events. Alcuin's intellectual commitment was first and foremost to a universe of divinely instituted harmony and order even when the visible course of the planets seemed to defy it.

\section{Appendix - translations from Alcuin's Letters 149 and 155}

Letters 149 and 155 are part of a larger corpus of letters between Alcuin and Charlemagne on learned questions ${ }^{68}$ Computus, astrono-

Interfaces $8 \cdot 2021 \cdot$ pp. 14-53

68. The letters are Alcuin, Epistulae $126,143,144,145,148,149,155,170,171$. 
69. All but 144 (sent by Charlemagne) occur in a large Tours collection represented by Troyes 1165 and other manuscripts transmitting larger assemblages of Alcuin letters; on $\mathrm{T}$ see Bullough 57-61. For the manuscript witnesses generally, see Dümmler's introduction and apparatus for each letter and the entry for each letter in Jullien.

70. With the adnominatio of Mars and martius, Alcuin calls attention to the etymological connection of war and the planet Mars, thus emphasising the fact that Mars reappeared during Charlemagne's campaign. Mars reappeared in mid-July in 798 according to the Lorsch Annals, which allows a dating of this letter and ep. 155 after mid-March. Tela martis here recalls Vergil Ecl. IX.12 and links this to the reminiscence of the Georgics at the start of the letter where Alcuin reflects on Charlemagne's request for a musical composition to calm the young warriors after battle. Vergilian framing of the two chief topics - the request for the song, and the explanation of Mars retrograde points to the element of display, literary ornament, and gratuitous revelling in learning that characterises the exchanges between Alcuin and Charlemagne across many years.

71. For the belief that the constellation Leo was the Nemean Lion slain by Hercules: Isidore, Etymologiae iii.lxxi.27.

72. Mars is in the sign of Cancer in April; in Leo, in June.

73. bimenstris/bimestris is an exceedingly rare word. It may be a lexical clue to Alcuin's memory of Pliny's discussion of Mars (Naturalis historia ii.19); Alcuin's use is the only example in the Dictionary of Medieval Latin from British Sources. The word was not used by Bede or Isidore.

74. Isidore, Etymologiae III.lxxi.15. Canis autem uocatur propter quod corpora morbo afficiat.

75. By making retrograde motion the reason the planets are called wandering, Alcuin elevates it from a glitch to a feature: an apparently disorderly event subsumed into a more inclusive order. my and the calendar are the central themes, but questions about other learned matters including grammar, exegesis, and worship are also considered. Astronomical matters other than planetary motion include the lunar saltation and the date of the new Easter cycle. The letters in this group are transmitted in various sub-groupings in over a dozen manuscripts of Alcuin's letters, not always in sequence; in some manuscripts only two or three of the letters occur. Thus these letters did not attain the status of a libellus and in this respect should be distinguished from various treatises on computistical matters attributed to Alcuin, some correctly, and others inaccurately. ${ }^{69}$ In modern terms, we might regard the astronomical speculation here as having remained unpublished. A number of the individual letters have been summarised by Lorhmann, Springsfeld, Borst, and Alberi though never translated. We offer here the excerpts about the motion of Mars from Ep. 149 and 155.

\section{Alcuin, Letter 149}

MGH Ep. 4, 243, from line 9:

... Now therefore, the planet Mars (which we have long sought) flashed forth suddenly amidst the martial spears. ${ }^{70}$ The sun held it back for a very long time, but let it go in terror of the Nemean lion [Leo], which is said to have been placed in the sky to commemorate the strength of Hercules. ${ }^{71}$ [Mars] passed from [the sign of] Cancer $^{72}$ in two months. ${ }^{73}$ And the sun, proceeding with a different course, will soon cause Mars to go backwards. Sirius also joins, radiant in appearance; it is very well-liked by doctors eager for payments. ${ }^{74}$

As to why the sun held [Mars] concealed for such a long time, the reason is, as the ancients would have it, the rays of the sun, which as is related, bring about the unequal courses of the planets. And on that account perhaps, [the planets] are said to be wandering, since they are known to not have an ever fixed course of a single type. ${ }^{75}$

Because if it is thus (as some reckoners would have it), then let the Egyptian boys tell why the sun and the moon be counted among them, seeing as they each have a course that is fixed in its years, months, days, hours, and minutes. For indeed they do not (actually) move erratically in [the heavens], as they say, even though they seem to go against the heaven, since they reach the turning points of their courses at precisely fixed times, just as the courses of the five planets are very often borne in an irregular way - whether by wandering or by standing or by going backwards - through the breadth of the circle of the zodiac. [Alcuin then moves on to other learned topics, including the adop-

Interfaces $8 \cdot 2021 \cdot$ pp. $14-53$ 
76. The hours that Mars is visible do depend on location; its place in the sky however does not depend on location. As Mars leaves the sun, if its ecliptic at star rise is vertically distant from the horizon, then you will notice it climbing in latitude. See Springsfeld $274-76$ for tables comparing of the timing of Mars' rising and setting in Saxony and Tours at the relevant dates.

77. That is, the task imposed by messenger Megenfrid, the musical composition Charlemagne requested from Alcuin to pacify the fierce tempers of his young warriors after battle.

78. Lemma in manuscript $\mathrm{T}$ (Troyes, Mediathèque du grand Troyes 1165, fol. 10).

79. Alcuin uses a range of bynames or personae in these two letters to dramatise his relationship with Charlemagne: he is variously the Old Entellus of Aeneid v.362-464 (the old boxer who shows such sudden power when angered that the match against his much younger opponent is called off); Flaccus (i.e. Horace, a byname associated by Alcuin with satire and moral criticism), and a veteran soldier, an alter ego borrowed from Jerome. Further, see Alberi and Springsfeld 246. tionist heresy and questions about the psalms, the liturgy, and a grammatical matter].

p. 245 lines 11-23:

To conclude the letter, Alcuin returns to the topic of Mars' retrograde motion

What happened recently with the star of Mars alone, this is also accustomed to happen very often with all of the five wandering stars [planets] in these regions: that they be hidden for longer than the regular page of the ancients declares. And perhaps the rising and setting of these stars does not take place equally for us who are dwelling in these northerly climes as it did for those who reside in the oriental or meridional parts of the world; ${ }^{76}$ for there, especially, were the masters who set out for us the rational principles and orbits (rationes et cursus) of heaven and of the stars. For many things vary on account of the difference of places, as your wisdom knows best. Now therefore, as we said before, we are making haste to faithfully accomplish our duty to you. ${ }^{77}$

\section{Alcuin Letter 155, To Charlemagne, September 798}

MGH Ep. IV, 249-53

Item, to the lord king on the course of the moon through the individual signs ${ }^{78}$

To King David, most noble in every kind of virtue and most resplendent in every ornament of wisdom, the veteran soldier Flaccus $^{79}$ [sends] greetings.

A traveller came flying, with an inquisitive letter in his hand from your authority, too brief in its number of syllables to have satisfied the eagerness of my mind, yet more profound in its questions than my humble wits could grasp, urging an old man with shaky understanding to explore celestial matters, when he has not yet learned the underlying principles of terrestrial things; (urging) one who can by no means recognise the natures of the plants growing upon the earth to expound the meandering courses of the wandering stars in heaven. And it would be a wonder how anyone might be able to reduce their erratic paths to a fixed order, since they are said to be 'wandering' precisely because they are thought to have unfixed (incertos) courses.

What new insight might our paltriness manage to discover in the daily travails of the moon, seeing as we have the regular principles 
8o. Lohrmann 97; Springsfeld 252.

81. Imago Martis here: recalls a line in the Aeneid: 'it timor et maior Martis apparet imago,' Aeneid viii.557: this is the fear of the people of Latium while Æneas and Pallas prepare their attack, the reference is rather to the god Mars, as a metonymy forward, than the planet. Alcuin thus nods to the mythic and astrological associations of Mars as god of war, even while disavowing all thought of portents and prodigies. (rationes regulares) investigated in the complex argumentation of the catholic teachers or of the ancient philosophers. For what can be said about the concord of the solar and lunar orbit through the signs of the zodiac that would be more lucid than what the investigator of such questions, the master Bede, has left for us in his writings? Or what could be discovered that is more insightful than what the most devoted discoverer of natural things, Plinius Secundus, expounded about the order of the heavenly bodies?

But since we are on a journey right now, we do not have at hand the books in which those things can be read. We do not dare to reply at all to the most profound questions of your wisdom; entreating your mercy, that you command to have sent to us the first books of the aforementioned expert Plinius Secundus, in which he strove to make intelligible the manifold and obscure arguments about the varying course of the stars; unless by chance, God willing, we may be able to dig out something here or there, which might seem worthy to be shown to your most holy presence.

However, - so that your letter would not find me thus unprepared or dumbstruck with sleepy inertia, - as if my memory had nothing laid by for itself in its private chamber, which it could offer to one inquiring, - I will say something on the spot, more seeking than expounding, which came to the attention of my discombobulated mind; reserving a fuller reply - if perhaps it will be required for the aforementioned books of the learned men.

[The letter continues with a full discussion of other matters related to lunar and solar cycles and the calendar. Alcuin cites Bede and Pliny and alludes in detail to the positions advanced in Charlemagne's letter. He also alludes to a diagram or figure, not transmitted with the letters, which clarified the matter. $]^{80}$

[Despite having informed and corrected Charlemagne, this section concludes with a courtier's deference: Alcuin writes:]

All of which things we know to be familiar to your wisdom.

[p. 251, line 29]

[Alcuin returns to the matter of Mars and continues: ]

Wherefore we begin to say what is observed about the planet Mars. Investigating this was vexing our mind for a long time, so that even its appearance was not enough to satisfy our curiosity. Recently while the sun was tarrying in Leo, [Mars] appeared to us, we think approximately, at the same time as the likeness of Mars ${ }^{81}$ appeared to 
82. Alcuin repeats the words of Charlemagne's question three times in all: first as a verbatim quotation, then as a close paraphrase but omitting the phrase 'past year;' finally, to refute them, in a modified form with the words 'entire past year' inserted order to contradict them specifically while seeming to agree with the rest of Charlemagne's observations. It is striking that, in the course of his exposition, Alcuin repeats the words naturalis cursus three times, emphasising order beneath apparent disorder. Here our translation concurs with Lohrmann 95-96 and diverges from Springsfeld 274-77.

83. Because Mars has a twenty-six month cycle.

84. The phrase is vi solis, so this is harking back to the solar ray theory, and to the use of the term vis on its own earlier in this letter. See ep. 149, p. 245, line 15. you. We likewise tried to say something about this planet according to the capacity of our inquiry in our other letter to your venerable highness (ep. 149, p. 243), soon after [Mars] appeared to us.

But now in response to the urging of your letter we have delved into the matter more scrupulously.

For you posed the question thus: "And about Mars, which, while in the sign of Cancer last year, was cut off from human sight by the light of the sun, what would you conclude: was that by the natural order of its course or (was it by reason) of the sun? Was it brought about by force or as a prodigy that it accomplished the journey of two years in one? For recently, after the sun left Leo, [Mars] appeared to us in the sign of Cancer. If (Mars) accompanied the sun, how could it be as swift in its course as [the sun]? If it took its place for the whole year in Cancer, why, when the sun migrated into other signs, was Mars not able to be seen in Cancer?"

A sophisticated and most acute argumentation, that! Let me respond to it as concisely as God will enable me to.

What is said there [is] "that the planet Mars was cut off from human sight while it was in Cancer." I do not judge that for the entire past year the planet Mars was cut off by the light of the sun in Cancer, but rather, that Cancer (along with the planet Mars), at the proper time and in the natural order of its course, was intercepted from human sight its course by the interposition of the earth. ${ }^{82}$ Therefore in the past year I do not recall having observed [Mars] in Cancer when Cancer was carrying out the order of its course beneath the earth by night.

Nor do I think it was an unnatural or portentous occurrence that [Mars] was not visible to us for so long, but rather, it was on account of the natural order of its course.

For if in the past year it did not appear in Cancer, and now appears in Cancer, then it is ascertained to traverse the extremity of its course not in one year but in the space of two years; ${ }^{83}$ seeing as now in the second year it is switched to another sign [of the zodiac].

This indeed was added [in the letter]: "if it took its position in Cancer for the whole year, with the sun moving into other signs, why was it not able to be seen in Cancer?"

Truly since Cancer itself, in which it took its position, could not be seen. Soon indeed when Cancer was able to be seen, Mars was also seen with Cancer, which for the past year set according to its natural course by nights, under the lands.

In another letter I wrote about the force of the $\operatorname{sun}^{84}$ causing unequal orbits for the wandering stars: 
85. Lucan's poem (and Isidore's) quotation in Etymologiae iii.65.3 read: radiisque potentibus; Alcuin or his assistant wrote anni for aevi and radiisque petentibus, a variant not attested as far as I know in Lucan or Isidore.

86. Lucan, De bello ciuili x.201-03; adduced by Isidore, Etymologiae iii.65.3.

87 . Troyes 1165 fol. $12 \mathrm{v}$ has no punctuation between the quotation and this sentence, thus creating a demonstration from the poetry.

As the poet said:

The sun divides the seasons of the year;

He changes day to night and with his assailing ${ }^{85}$ rays,

Himself hinders [the planets] and retards their

wandering courses with a standstill ${ }^{86}$

Which thing Saturn, Juliter and Mars are most often observed to undergo. ${ }^{87}$

May your venerable wisdom and most acute intelligence consider, whether in this [letter] or in that one, anything might seem worthy or plausible, or whether something different should be believed about such questions. For I have not at all considered that you asked the question on out of ignorance. Whatever you might judge from this I pray that you will not hesitate from letting us know with good will. For I am not a diehard advocate of my own opinion, but a devoted adherent of truth.

[the letter then returns to the notes about the appended figure and the calculation of hours when the individual signs rise or set or move from their place]

All these things I have gathered into one representation for the sake of convenience of knowing the course of the moon; may your most excellent wisdom ascertain whether the rationale is truly discovered.

Alberi, Mary. "Jerome, Alcuin and Vergil's 'Old Entellus.”' Journal of Medieval History, 17.2 (1991), 103-113. Al-Bitrūjī. On the Principles of Astronomy. Volume 1. Translated by Bernard R. Goldstein. New Haven: Yale University Press. Alcuin. Carmina. Poetae Latini Carolini Aevi I. Edited by Ernst Dümmler. Monumenta Germaniae Historica. Berlin: Weidmann, 1881. ---. Epistolae. Epistolae IV, Epistolae Karolini Aevi II. Edited by Ernst Dümmler. Monumenta Germaniae Historica,. Berlin: Weidmann, 1895: 1-481.

---. The Bishops, Kings, and Saints of York. Edited and translated by
Peter Godman. Oxford: Oxford University Press, 1982.

Alcuin. De uera philosophia. Edited by André Duchesne. Rpt. Patrologia Latina 101. Paris: J.P. Migne, 1863. 849-854.

Aldhelm. Epistola ad Acircium. Opera Omnia. Edited by Rudolf Ewald. Monumenta Germaniae Historica. Auctores Antiquissimi 15. Berlin, 1919.

Aldhelm. The Prose Works. Translated by Michael Lapidge and Michael Herren. Cambridge: D. S. Brewer, 1979.

Annales regni Francorum inde ab A. 741 usque ad A. 829, qui dicuntur Annales Laurissenses maiores et Einhardi. Monumenta Germaniae 
Historica, Scriptores rerum Germanicarum in usum scholarum separatim editi, Monumenta Germaniae Historica. Edited by Georg H. Pertz and Friedrich Kurze. Hannover: Hahn, 1895. Archimedes, Arenarius. Archimède tome II: Des spirales, de léquilibre des figures planes, l'arénaire, la quadrature de la parabole. Edited and translated by Charles Mugler. Paris: Les Belles Lettres, 1971. 134-157. Aristotle. De Caelo. Translated by John L. Stocks and Harry B. Wallace. Oxford: Oxford University Press, 1922.

---. Metaphysics. In Metaphysics, volume II: Books 10-14. Oeconomica. Magna Moralia. Translated by G. Cyril Armstrong and Hugh Tredennick. London: Harvard University Press, 1935.

Augustine. On Christian Teaching. Translated by R.P. H. Green. Oxford: Oxford University Press, 2008.

Barker-Benfield, Bruce. "Macrobius." Texts and Transmissions: A Survey of the Latin Classics. Edited by Leighton D. Reynolds, et al. Oxford: Clarendon Press, 1983: 222-234.

Barney, Stephen A., W. J. Lewis, J. A. Beach, and Oliver Berghof. The Etymologies of Isidore of Seville. Cambridge: Cambridge University Press, 2006.

Bede. The Reckoning of Time. Translated with introduction, notes and commentary by Faith Wallis. LTTH 29. Liverpool: Liverpool University Press, 1999. ---. On the Nature of Things and On Times. Translated by Faith Wallis and Calvin Kendall. LTTH 56. Liverpool: Liverpool University Press, 2010.

Berschin, Walter. Greek Letters and the Latin Middle Ages: from Jerome to Nicholas of Cusa. Translated by Jerold C. Frakes. Washington:
Catholic University of America, 1988.

Bischoff, Bernhard. Manuscripts and Libraries in the Age of Charlemagne. Translated by Michael Gorman.

Cambridge Studies in Palaeography and Codicology 1. Cambridge: Cambridge University Press, 2014. ---. Katalog der festländischen Handschriften des neunten Jahrhunderts (mit Ausnahme der wisigotischen), vol. 3: Padua - Zwickau, aus dem Nachlaß. Edited by Birgit Ebersperger. Wiesbaden: Harassowitz, 2014. Bayerische Akademie der Wissenschaften. Veröffentlichungen der Kommission für die Herausgabe der mittelalterlichen Bibliothekskataloge Deutschlands und der Schweiz.

Böhmer, Johann F., Engelbert Mühlbacher, Johann Lechner. Regesta Imperii I. Die Regesten des Kaiserreichs unter den Karolingern 751-918 . $2^{\text {nd }}$ edition. Innsbrück: Wagner, 1908.

Borst, Arno Das Buch der Naturgeschichte: Plinius und seine Leser im Zeitalter des Pergaments. 1994. 2nd improved edition, Heidelberg: Winter, 1995.

---. "Alkuin und die Enzyklopädie von 809." Science and Western and Eastern Civilization. Edited by Butzer and Lohrmann, 53-78. Bullough, Donald. Alcuin: Achievement and Reputation, being part of the Ford Lectures delivered in Oxford in Hilary Term 1980.

Leiden, Brill, 2004.

Burton, Philip. "The Vocabulary of the Liberal Arts in Augustine's Confessions." Augustine and the Disciplines: From Cassiciacum to Confessions. Edited by Karla Pollmann and Mark Vessey. Oxford: Oxford University Press, 2009. 141-164.

Butzer, Paul Leo and Dietrich Lohrmann, editors. Science in
Western and Eastern Civilization in Carolingian Times. Basel: Birkhäuser, 1993.

Cassiodorus. Institutiones. Ed. R.A.B. Mynors. Oxford: Clarendon, 1937.

---. Institutions of Divine and Secular Learning and On the Soul. Translated by James W. Halporn, introduction by Mark Vessey. LTTH 42. Liverpool: Liverpool University Press, 2004.

Cassiodorus Senatorus. Variae. Monumenta Germaniae Historica Auctores Antiquissimi XII. Edited by Theodorus Mommsen. Berlin: Weidmann, 1894.

---. Cassiodorus: Variae, translated with notes and an introduction. Translated by S.J.B. Barnish, TTH 12. Liverpool: Liverpool University Press, 1992.

Corrigan, Sarah. "Hisperic Enigma Machine: Sea creatures and sources in the Hisperica Famina." Peritia 24-15 (2013-2014): 59-79.

Courcelle, Pierre. Late Latin Writers and their Greek Sources. Translated by Harry Wedeck. Cambridge: Harvard University Press, 1969. Dobcheva, Irene. "The Umbrella of Carolingian Computus." La compilacíon del saber en la edad media/La compilation du savoir au moyen âge/The Compilation of knowledge in the Middle Ages. Editado por María José Muñoz, Patricia Cañizares y Cristina Martín. Fédération Internationale des Instituts d'Études Médiévales. Textes et etudes du moyen âge 69 . Porto: Fédération Internationale des Instituts d'Études Médiévales, Gabinete de Filosofia Medieval / Faculdade de Letras da Universidade do Porto, 2013. 211-230.

Dutton, Paul. "Of Carolingian Kings and their Stars." In his Charlemagne's Moustache and Other Cultural Clusters of a Dark Age. 
New York: Palgrave McMillan, 2004. 93-128.

Eastwood, Bruce S. “The Revival of Planetary Astronomy in Carolingian and Post-Carolingian Europe." Journal for the History of Astronomy, 35 (2004): 109-111.

---."The astronomy of Macrobius in Carolingian Europe: Dungal's letter of 811 to Charles the Great." Early Medieval Europe 3 (1994): 117-134. ---. Ordering the Heavens: Roman Astronomy and Cosmology in the Carolingian Renaissance. Leiden: Brill, 2007.

---. “The Power of Diagrams: the Place of the Anonymous Commentary in the Development of Carolingian Astronomy and Cosmology." Carolingian Scholarship and Martianus Capella: Ninth-Century Commentary Traditions on 'De nuptiis' in Context. Edited by Mariken Teeuwen and Sinéad O'Sullivan. Turnhout: Brepols. 193-220. Einhard. Vita Karoli. Edited by Georg Waitz and Georg H. Pertz. Monumenta Germaniae Historica Scriptores rerum germanicarum in usum scholarum. Hannover:

Hahn, 1911.

Einhard. "The Life of Charlemagne." Charlemagne's Courtier: The Complete Einhard. Ed. Trans. Paul Dutton. Toronto: Broadview, 1998: 15-40.

Folkerts, Menso. Euclid in Medieval Europe. Questio II, de rerum natura. The Benjamin Catalogue for the History of Science. Winnipeg, 1989. Fontaine, Jacques. Isidore de Seville et la culture classique dans l'espagne wisigothique. Paris: Études Augustiniennes, 1959. Tom. 2. Garrison, Mary. "Alcuin, Carmen ix and Hrabanus Ad Bonosum: A Teacher and his Student write Consolation." Poetry and Philoso- phy in the Middle Ages: A Festschrift for Peter Dronke. Edited by John Marenbon. Leiden: Brill, 2000. 63-78.

---. “An Insular Copy of Pliny's Naturalis historia (Leiden VLF 4 fols 4-33)." In Writing in context. Insular manuscript culture, 500-1200. Edited by Erik Kwakkel. Leiden: Leiden University Press, 2013. 67-126.

---. "The Library of Alcuin's York."

The Cambridge History of the Book in Britain volume 1: ca. 400-110o.

Ed. Richard Gameson. Cambridge, 2011. 134-202.

Gingerich, Owen. The Eye of Heaven: Ptolemy, Copernicus, Kepler. Princeton: Princeton University Press, 1997.

Glauthier, Patrick. Science and Poetry in Imperial Rome: Manilius, Lucan, and the Aetna, unpublished $\mathrm{PhD}$ dissertation. Columbia University, New York, 2011.

Gotoff, Harold C. The Transmission of Lucan in the Ninth Century. Cambridge: Harvard University Press, 1971. [Not available to us at the time of writing].

Grant, Edward. The Foundations of Modern Science in the Middle Ages. Cambridge: Cambridge University Press, 1996.

Grosseteste, Robert. De Sphera. Edited by Cecilia Panti. Moti, virtù e motori celesti nella cosmologia di Roberto Grossatesta. Studio ed edizione dei trattati "De sphera», "De cometis», "De motu supercelestium». Florence: SISMEL Edizioni del Galluzzi, 2001. 285-319.

Hartmann, Martina. "Alcuin et la gestion matérielle de Saint-Martin de Tours." Alcuin de York à Tours. Edited by Philippe Depreux and Bruno Judic. Annales de Bretagne. vol. 111, 3 (2004): 91-102.

Hine, Harry M. “The Manuscript
Tradition of Seneca's Naturales quaestiones: addenda." Classical Quarterly 42 (1992): 558-62. Ineichen-Eder, Christine. “Theologisches und philosophisches Lerhmaterial aus dem Alcuin-Kreise". Deutsches Archiv für Erforschung des Mittelalters 34 (1978), 192-201.

Isidore of Seville. Etymologiarum siue originum libri $\mathrm{Xx}$. Ed. Wallace M. Lindsay. Oxford: Clarendon, 1911. Tomus I.

---. Traité de la Nature suivi de lépître en vers du roi Sisebut à Isidore. Edited by. Jacques Fontaine. Paris: Etudes Augustiniennes, 2002. Jaeger, Stephen. "Alcuin and the Music of Friendship." Modern Language Notes 127.5 (2012): 105-125. Jones, Alexander. "Pliny on the Planetary Cycles." Phoenix 45.2 (1991): 148-161.

Jullien, Marie-Hélène and Françoise Perelman. Clavis des Auteurs Latins du moyen âge, territoire français 735-987. Turnhout: Brepols, 1999. Lapidge, Michael. The Anglo-Saxon Library. Oxford: Oxford University Press, 2006.

Lohrmann, Dietrich. "Alcuins Korrespondenz mit Karl dem Großen über Kalendar und Astrononie." Science in Eastern and Western Civilization in Carolingian Times. Edited by Paul Leo Butzer and Dietrich Lohrmann. Basel: Birkhäuser, 1993: 79-114.

Lucan. De bello ciuili. Edited by William Heitland. Corpus poetarum latinorum: a se aliisque denuo recognitorum et brevi lectionum varietate instructorum. Vol. 2. Compiled by John Percival Postgate. London: Bell, 1905. 83-144. ---. The Civil War, books I-X. Translated by James D. Duff. London: Heinemann, 1928. 
Macrobius. Commentary on the Dream of Scipio. Translation, introduction, notes by William Harris Stahl. New York: Columbia University Press, 1952.

Marenbon, John. From the Circle of Alcuin to the School of Auxerre: Logic, Theology, and Philosophy in the Early Middle Ages. Cambridge: Cambridge University Press, 1981. Martianus Capella. Carolingian Scholarship and Martianus Capella: The Oldest Commentary Tradition. Mariken Teeuwen et al., eds. Digital edition. 1st ed.

November 2008. Online. Accessed 21 May 2020.

---. Martianus Capella and the Seven Liberal Arts, volume 2: The Marriage of Philology and Mercury. Translated by William H. Stahl and Richard Johnson. New York: Columbia University Press, 1977. ---. William H. Stahl, Richard Johnson and Evan L. Burge. Martianus Capella and the Seven Liberal Arts, volume 1: The Quadrivium of Martianus Capella: Latin Traditions in the Mathematical Sciences 50 B.C. - A.D. 1250. New York: Columbia University Press, 1971.

McLuskey, Stephen. Astronomies and Cultures in Early Medieval Europe. Cambridge: Cambridge University Press, 1998.

---. "Martianus and the Traditions of Early Medieval Astronomies." Carolingian Scholarship and Martianus Capella: Ninth-Century Commentary Traditions on 'De nuptiis' in Context. Edited by Mariken Teeuwen, and Sinéad O'Sullivan, Turnhout: Brepols, 2011 221-244. 221-2.

Nelson, Janet. King and Emperor: A New Life of Charlemagne. Harmondsworth, Penguin, 2019. Notker the Stammerer. "Charlemagne.” Translated by Lewis
Thorpe in his Einhard and Notker the Stammerer: Two Lives of Charlemagne. Harmondsworth: Penguin, 1969. 93-172.

Pliny. C. Plinii secundi, Naturalis Historiae libri xxxvii post Ludovici Iani obitum recognovit et scripturae discrepantia adiecta ed. Carolus Mayhoff, vol. I, books I-VI. Stuttgart: Teubner, 1906. ---. Natural History I: Books I-II. Translated by Harris Rackham. London: Heinemann, 1949.

Plutarch. De facie quae in orbe lunae apparet. Translated by Harold Cherniss and William C. Helmbold. Moralia, volume XII: Concerning the Face Which Appears in the Orb of the Moon. On the Principle of Cold. Whether Fire or Water Is More Useful. Whether Land or Sea Animals Are Cleverer. Beasts Are Rational. On the Eating of Flesh. Edited by Jeffrey Henderson. London, Harvard University Press, 1954. 34-223.

Ramirez-Weaver, Eric. M. A Saving Science. Capturing the Heavens in Carolingian Manuscripts. University Park: Pennsylvania State University Press, 2017.

Reeve, Michael D. “The Editing of Pliny's Natural History." Revue d'histoire des textes n.s. II (2007) 107-179.

Reynolds, Leighton D. ed. Texts and Transmissions: A Survey of the Latin Classics. Oxford: Clarendon. 1983. ---. "The Elder Pliny." In his Texts and Transmissions. 307-316.

Russo, Lucio. The Forgotten Revolution: How Science was Born in 300 $B C$ and why it had to be reborn. 1996. Translated by Silvio Levy. Milan: Springer, 2003.

Sargent, Noel. "The early history of the theory of eccentrics and epicycles." Popular Astronomy 25 (1917): 285-88.

Seneca, Lucius Annaeus. Natural
Questions. Translated by Harry M. Hine. Chicago: University of Chicago, 2010.

---. L. Annaei Senecae. Naturalium

Quaestionum libri. Edited by Harry

M. Hine. Stuttgart: Teubner, 1996.

Simplicius. On Aristotle Physics 2.

Translated by Barrie Fleet.

London: Bloomsbury Academic, 2013. 9-160. Ancient Commentators on Aristotle. Bloomsbury Collections. Web. 21 May 2020. Springsfeld, Kerstin. Alkuins Einfluß auf die Komputistik zur Zeit Karls des Großen. Sudhoffs Archiv 48. Stuttgart: Franz Steiner, 2002. Stevens, Wesley. "Astronomy in Carolingian Schools." Charlemagne and his Heritage: 1200 Years of Civilization and Science in Europe, volume I: Scholarship, Worldview, and Understanding. Edited by Paul L. Butzer, Max Kerner and Walter Oberschelp. Turnhout: Brepols, 1997. 417-88.

William H. Stahl, Richard Johnson and Evan L. Burge. Martianus Capella and the Seven Liberal Arts, volume 1: The Quadrivium of Martianus Capella: Latin Traditions in the Mathematical Sciences 50 B.C. - A.D. 1250 . New York: Columbia University Press, 1971. Tarrant, Richard J. "Lucan." Texts and Transmission. Edited by Leighton D. Reynolds. Oxford: Clarendon, 1983. 215-218.

Tupikova, Irena. “A Technical Note on Epicyclical Interpretations of Pliny's Planetary Theory." Journal of Interdisciplinary History of Ideas 3 (2014): 7b:1-7b:10.

Warntjes, Immo. The Munich Computus: text and translation: Irish computistics between Isidore of Seville and the Venerable Bede and its reception in Carolingian Times. Sudhoffs Archiv. Beihefte, Heft 59. Stuttgart: Franz Steiner, 2010. 